\title{
The functional architecture of the acetylcholine nicotinic receptor explored by affinity labelling and site-directed mutagenesis
}

\author{
JEAN-PIERRE CHANGEUX ${ }^{1}$, JEAN-LUC GALZI ${ }^{1}$, \\ ANNE DEVILLERS-THIÉRY ${ }^{1}$ AND DANIEL BERTRAND ${ }^{2}$ \\ 'Institut Pasteur, Neurobiologie Moléculaire, CNRS DI284, Département des Biotechnologies, 25, rue du \\ Docteur Roux, 75015 Paris, France \\ ${ }^{2}$ Centre Médical Universitaire, Département de Physiologie, CH-I21. Geneva, Switzerland
}

I. THE NICOTINIC RECEPTOR SITES 398

I. I The diversity of nicotinic receptor sites 398

I.2 Identification of amino acids composing the binding areas for nicotinic ligands 400

I.3 Site directed mutagenesis of the amino acids identified by affinity labelling 402

I.4 Models of the nicotinic receptor site 403

2. IDENTIFICATION AND MAPPING OF THE ION CHANNEL 406

2. I Affinity labelling by non-competitive blockers 406

2.2 The MII segment is a component of the ion channel 407

2.3 Exploration of MII function by site directed mutagenesis $4 \mathrm{IO}$

3. ALLOSTERIC INTERACTIONS BETWEEN THE NICOTINIC RECEPTOR SITES AND THE ION CHANNEL 412

3. I Activation of the ion channel 412

3.2 Regulation by desensitization of the permeability response to nicotinic agonists 414
4. CONCLUSIONS $4 \mathrm{I} 8$
5. ACKNOWLEDGEMENTS 4I9
6. REFERENCES 4 I 9

The scientific community will remember Peter Läuger as an exceptional man combining a generous personality and a sharp and skilful mind. He was able to attract by his views the interest of a large spectrum of biologists concerned by the mechanism of ion translocation through membranes. Yet, he was not a man with a single technique or theory. Using an authentically multidisciplinary approach, his ambition was to 'understand transmembrane transport at the microscopic level, to capture its dynamics in the course of defined physiological processes' ( 1987 ). According to him, 'new concepts in the molecular physics of proteins' had 
to be imagined, and 'the traditional static picture of proteins has been replaced by the notions that proteins represent dynamic structures, subjected to conformational fluctuations covering a very wide time-range' (1987).

The work presented in this brief review on the functional architecture of the acetylcholine receptor may not have satisfied Peter Läuger. Indeed, we are not yet at a stage where the regulation of ion translocation mediated by a ligand-gated ion channel, the acetylcholine receptor, can be described in terms of the precise mechanisms he elaborated with so much success. Yet, in the past two decades, experimental and theoretical work has unravelled several basic principles about the functional organization and conformational transitions of this rather complex protein. The level of resolution reached is that of single amino acid residues. A more complete description will require the high resolution three-dimensional structure which has not yet been determined.

The acetylcholine 'nicotinic' receptor is the pharmacological receptor for the neurotransmitter acetylcholine at junctions between motor nerve and skeletal muscle and at brain synapses. It is the target of pharmacological agents referred to as 'nicotinic' by Dale (I9I4) which include nicotine among the agonists, dtubocurarine among the competitive antagonists.

The primary function of the nicotinic acetylcholine receptor is to mediate signal transmission at the postsynaptic level. At the motor endplate, acetylcholine is liberated by the nerve ending in the synaptic cleft as a high local concentration pulse ( $100 \mu \mathrm{M}$ to $\mathrm{I} \mathrm{mm}$ in less than I ms) (Kuffler \& Yoshikami, I 975; Katz \& Miledi, I977) binds to specific sites on the receptor protein and triggers the opening of the associated cation-selective channel in a fast ( $\mu \mathrm{sec}$ to $\mathrm{msec}$ ) all-or-none manner, referred to as activation reaction (Katz, I 966; Katz \& Miledi, 1970; Neher \& Sakmann, I $976 a, b)$. Upon prolonged exposure to acetylcholine, or to a variety of pharmacological agents, the receptor is subject to a higher order regulation. It exhibits reversible slow (100 $\mathrm{ms}$ to $\mathrm{min}$ ) decrease in response amplitude termed desensitization which has been observed both at the motor endplate (Katz \& Thesleff, I957; Sakmann et al. I980; Ochoa et al. 1989) and with neuronal receptor (Ochoa et al. 1992).

The receptor for acetylcholine was initially isolated (Changeux et al. I 970 $a, b$ ) from fish electric organ (Nachmansohn, I959) with the help of snake venom $\alpha$ toxins as highly specific ligands (Lee \& Chang, I 966). It was identified as a single macromolecular entity, a transmembrane glycoprotein of $290 \mathrm{kDa}$ (Changeux, I 98 I, I 990) composed of four distinct subunits assembled into an heterologous pentamer $2 \alpha \beta \gamma \delta$ (Karlin, I99I). Reconstitution of the ionic response to the agonists with the purified receptor protein (Popot et al. 1981) and subunit mRNA expression experiments in frog oocytes (Numa, 1989) further demonstrated that the $2 \alpha \beta \gamma \delta$ oligomer contains all the structural elements required for the physiological response: the binding sites for agonists and competitive antagonists, the ion channel and the mechanisms which ensure fast and slow coupling (or uncoupling) between these two categories of sites (Galzi et al. I99 I $a$; Cockcroft et al. I 992; Ochoa et al. 1989, I 992). With neuronal receptor, assembly of only two categories of subunits ( $\alpha$ and $\beta$ ) (Heinemann et al. I 989; Schoepfer et al. I 989) and 

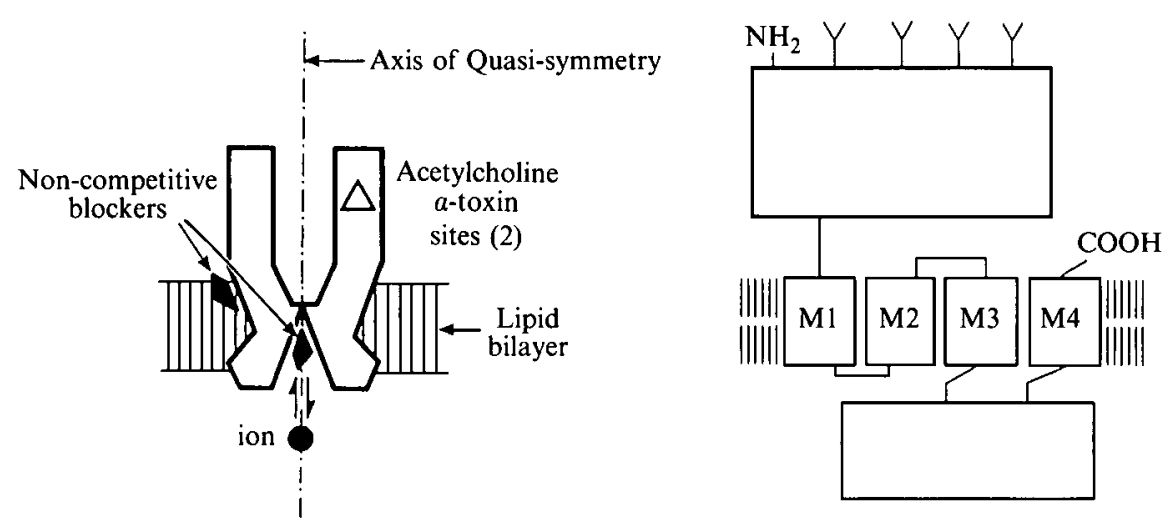

Fig. I. Schematic representation of the quaternary structure of the acetylcholine receptor oligomer (left) and of the transmembrane folding common to all subunits (right) (modified from Changeux et al. 1984$)$.

of even only one ( $\alpha 7$ subunit) (Schoepfer et al. 1990; Couturier et al. 1990a) in Xenopus oocytes suffices to yield a functional receptor which also desensitizes but may display an ionic selectivity (high permeability to $\mathrm{Ca}^{2+}$ ) distinct from that of the muscle receptor (Mulle et al. 1992; Vernino et al. 1992).

On the basis of the primary amino acid sequence data of the purified subunits (Devillers-Thiéry et al. I 979; Raftery et al. 1980), the cDNA and genes coding for the several subunits of electric organ and skeletal muscle receptor were cloned and sequenced (Noda et al. 1982, 1983a, $b$; Claudio et al. 1983; Devillers-Thiéry et al. i 983 , Numa, 1989).

The aligned sequences of the various receptor subunits appear strongly homologous and show similar hydrophobicity profiles, justifying a common subdivision of the homologous chains into: $(a)$ a large hydrophilic amino-terminal domain of 2 I $0-220$ amino acids; $(b)$ a compact hydrophobic region of 70 residues subdivided into three segments of $19^{-27}$ uncharged amino acids (MI, MII, and MIII); (c) a second hydrophilic domain of variable length, generally much larger in the neuronal subunits; $(d)$ a carboxy-terminal segment of 20 hydrophobic residues (MIV). On the basis of these primary sequence data, several models of transmembrane organization common to all four subunits have been proposed (Popot \& Changeux, 1984; Stroud et al. 1990; Galzi et al. 1991 a). The presently most adequate one (Fig. I) postulates (Claudio et al. I 983 ; Devillers-Thiéry et al. 1 $98_{3}$; Noda et al. $\left.198_{3} b\right):(a)$ the orientation of the large hydrophilic domain towards the synaptic cleft; $(b)$ the orientation of the small hydrophilic domain towards the cytoplasm; $(c)$ the assignment of the four hydrophobic segments MI-MIV to transmembrane $\alpha$-helices traversing the lipid bilayer four times in such a manner that the $\mathrm{COOH}$ terminal faces the synaptic cleft (McCrea et al. 1987; Di Paola et al. I 989). Accordingly, the active site would be primarily located in the large hydrophilic domain on the $\alpha$-subunit and the walls of the ion channel lying on the axis of quasi-symmetry of the receptor oligomer would be delineated by a homologous transmembrane segment from each subunit.

The data summarized in this review are consistent with this scheme. They also 
support the concept that the acetylcholine receptor is an allosteric protein (see Changeux, 1965, 1966, 1969; Changeux et al. 1967a) which mediates indirect interactions (Changeux, 1961; Gerhart \& Pardee, 1962; Monod et al. 1963) between topographically distinct sites (the acetylcholine-binding sites and the ion channel) via discrete all-or-none transitions of its tertiary and quaternary structure (Monod et al. 1965; Rubin \& Changeux, I966).

\section{THE NICOTINIC RECEPTOR SITES}

\section{I The diversity of nicotinic receptor sites}

Nicotinic agonists cause the opening of the ion channel when they interact with nicotinic 'receptor sites' carried by the oligomeric pentamer $(2 \alpha \beta \gamma \delta)$ from electric organ (or muscle), and by the neuronal $\left(n \alpha_{\mathrm{i}} m \beta_{\mathrm{j}}\right)$ receptor. Their effect is blocked by competitive antagonists like $d$-tubocurarine or dihydro- $\beta$-erythroidine, yet, with different selectivities for the various muscle and neuronal receptors (Luetje et al. 1990; Couturier et al. 1990b; Galzi et al. 1991 a; Ochoa et al. 1992). Also, $\alpha$-bungarotoxin typically blocks electric organ and muscle receptors but not neuronal receptors except those containing the $\alpha_{7}$ subunit (Couturier et al. 1990a). Some species of neuronal nicotinic receptor are blocked by neuronal bungarotoxin (Loring et al. 1984 ), but not others (Papke et al. 1989; Duvoisin et al. 1989).

Such differences in sensitivity to antagonists (and also in single channel properties) (see Katz \& Miledi $1973 a$; Neher \& Sakmann, I $976 a, b$; Lipton $e t a l$. 1987; Aracava et al. 1987; Mulle \& Changeux, r 990; Mulle et al. I991) support the view that pharmacologically distinct sub-species of nicotinic receptors exist both in the central nervous system and at the periphery. Despite these differences, all agonists and competitive antagonists exert their effect upon binding to common homologous areas of the protein molecule which are viewed as allosteric regulatory sites where the pharmacological ligands elicit signal transduction without being chemically transformed (see Monod et al. 1963).

The two $\alpha$-subunits present per receptor oligomer contribute to the binding area for nicotinic ligands in electric organ, muscle and at least in some neuronal receptor molecules (Karlin, I 980, I99 I; Galzi et al. I 99 I $a$; Cockcroft et al. I992). Consistent with this structural feature, two main acetylcholine binding sites exist per electric organ receptor molecule (Reynolds \& Karlin, I 978) and these two sites interact in a positively cooperative manner (Weber \& Changeux, I974a-c; Cohen et al. 1974; Changeux, 1990). The two $\alpha$-subunits are not adjacent within the $2 \alpha \beta \gamma \delta$ oligomer (Bon et al. 1982, I984; Karlin, 1983 ; Brisson \& Unwin, 1985 ; Stroud et al. I 990). The homotropic interactions between nicotinic binding sites are thus indirect or allosteric.

Yet, on Torpedo receptor the positive cooperative interactions between acetylcholine molecules take place between non-equivalent sites. These sites differ by their kinetics of $\alpha$-toxin binding (Weber \& Changeux, 1974 $a, b$; Maelicke \& Reich, 1976; Maelicke et al. 1977; Conti-Tronconi et al. 1990), by their affinities for $\left[{ }^{3} \mathrm{H}\right] \mathrm{d}$-tubocurarine (Neubig \& Cohen, 1979, 1980; Pedersen \& Cohen, 
I 990a) and for several affinity reagents (Damle et al. I978; Deleglane \& McNamee, I 980; Culver et al. 1984; Ratnam et al. 1986) and by their reactivity toward antibodies (Watters \& Maelicke, I983; Gu et al. 1985; Whiting et al. 1985 ; Dowding \& Hall, 1987).

The two $\alpha$-subunits are encoded by a single gene in Torpedo (Klarsfeld et al. I 984) and mouse (Merlie et al. I983) and thus are, most likely, identical in primary structure and possibly in tertiary structure (see Galzi et al. I99 r $a, b$ ). However, within the $2 \alpha \beta \gamma \delta$ oligomer, the two $\alpha$-subunits cannot be equivalent in their mode of interaction with other subunits (see Neubig \& Cohen, r 979; Karlin, I980, for discussion) which plausibly contribute domains for ligand binding. Indeed, UV irradiation of the $\left[{ }^{3} \mathrm{H}\right] \alpha$-toxin-receptor complex results in the covalent incorporation of radioactivity in the $\gamma$ - and $\delta$-subunits in addition to the $\alpha$ subunit (Oswald \& Changeux, 1982). Furthermore, significant carbamylcholinesensitive incorporation of $N, N$-(dimethylamino)benzenediazonium fluoroborate (DDF) (see following paragraph) occurs on the $\gamma$-subunit (Langenbuch-Cachat $e t$ al. 1988). Also, $\left[{ }^{3} \mathrm{H}\right] \mathrm{d}$-tubocurarine photoaffinity labels the $\alpha$ - and $\gamma$-subunits when bound to its high-affinity site and the $\alpha$ - and $\delta$-subunits when bound to its low-affinity site (Pedersen \& Cohen, I990a). Moreover, expression of different pairs of mouse muscle $\alpha$ - and non $\alpha$-subunits in fibroblasts show that the $\gamma$ - and the $\delta$-subunits associate efficiently with the $\alpha$-subunit (Kurosaki et al. 1987) into $\alpha \gamma-\alpha \delta$ complexes with different binding affinities for the competitive antagonist $d-$ tubocurarine (Blount $\&$ Merlie, I 989). The association of the non $\alpha$-subunits, in particular the $\gamma$ - and $\delta$-subunits, also affects the cooperativity of ligand binding to the receptor from mouse muscle (Sine $\&$ Claudio, I 99 I). The non-equivalence of acetylcholine binding sites may thus result from the association of each $\alpha$-subunit with either the $\gamma$ - or $\delta$-subunit and the two binding areas for nicotinic ligands would span the boundaries between subunits, as it occurs with other specific sites on regulatory proteins, such as phosphofructokinase (Perutz, I 989).

To date, the situation is less documented with the various forms of neuronal nicotinic receptor. Association of $\alpha$ - and non- $\alpha$-subunits into a pentameric oligomer is considered as necessary for function (Cooper et al. 199 I; Anand et al. I 99 I), with the notable exception of the $\alpha 7$ subunit from chick brain which forms functional homooligomers in Xenopus oocytes (Couturier et al. 1990a). Different assemblies of neuronal nicotinic receptor subunits yield, in Xenopus oocytes, functional receptors with different affinities for acetylcholine and different pharmacological specificities (for review Luetje et al. 1990; Ochoa et al. 1992). At this stage, the actual subunit composition of nicotinic receptors in the brain is largely unknown and the occurrence of pharmacologically non-equivalent (or equivalent) acetylcholine binding sites has not been demonstrated. Yet, the recent progress of the molecular biology of brain nicotinic receptors reveals that distinct subunits may display different patterns of topological expression within the brain, thereby paving the way to a nicotinic pharmacology targeted to defined brain areas. 


\section{I.2 Identification of amino acids composing the binding areas for nicotinic ligands}

The method of covalent labelling by a high-affinity, chemically reactive ligand has been widely used to explore the structure of the acetylcholine binding areas and led to the first successful identification of amino acids which compose this site. Initially, the compound $p$-(trimethylammonium)benzene diazonium difluoroborate (TDF) (Fenton \& Singer, I 965) was selected for its homology with the nicotinic agonist phenyltrimethyl ammonium and for the presence of a highly reactive diazonium group (Changeux et al. 1967 b). TDF irreversibly blocked the response to carbamylcholine in a d-tubocurarine sensitive manner (Changeux et $a l$. $1967 b)$ and the incorporation of about one molecule per $\alpha$-toxin binding site sufficed to completely block the binding of acetylcholine to the receptor (Weiland et al. 1979). Several less chemically reactive alkylating analogs of nicotinic ligands such as the maleimide homologue of TDF [4-( $N$-maleimido $)$ phenyl trimethyl ammonium iodide (MPTA)], has also been used with improved selectivity (Karlin \& Winnick, I968). With Torpedo receptor the cysteine residues 192 and possibly I93, a tandem unique to the $\alpha$-subunit, incorporate the affinity label (MBTA) (Kao et al. 1984) (Figs 2, 4). This labelling, however, occurs exclusively on the reduced receptor since in the native receptor, Cys 192 and 193 are linked by a disulphide bridge (Kao \& Karlin, 1986; Mosckovitz \& Gershoni, I988). Subsequent studies, based on the binding of snake $\alpha$-toxins to $\alpha$-subunit fragments, to synthetic peptides (Wilson et al., I 985 ; Radding et al., I 988 ; MulacJericevic \& Atassi, 1986; Ralston et al. 1987), deletion mutants (Barkas et al. 1987), or $\alpha$-subunit fragments expressed in Escherichia coli transformants (Gershoni, I987), as site-directed mutagenesis experiments (Mishina et al. I 985), confirmed that the region containing Cysi 92-I93 contributes to the interaction of cholinergic ligands and snake $\alpha$-toxins with the $\alpha$-subunit.

Significant improvement in the mapping of the amino acids from the nicotinic binding sites has been obtained with DDF, the $N$-dimethyl homologue of TDF (Langenbuch-Cachat et al. I 988) (Fig. 2). In the dark DDF behaves as a reversible competitive antagonist of the electrical response of Electrophorus electricus electroplaque and of the acetylcholine-gated single-channel currents recorded in the $\mathrm{C}_{2}$ mouse cell line. Moreover DDF can be efficiently photoactivated by an energy transfer reaction between an excited tryptophan residue from the ligandbinding site and the photosensitive ligand. Such a procedure significantly improved the specificity of the labelling and was named 'photosuicide inactivation' (Goeldner \& Hirth, I980; Goeldner et al. I982). Under such irradiation conditions, DDF reacts with Torpedo marmorata receptor without prior reduction and labels the nicotinic ligand binding site with a stoichiometry of one DDF incorporated per $\alpha$-bungarotoxin binding site (Langenbuch-Cachat et al. 1988). Interestingly, the amino acids labelled by $\left[{ }^{3} \mathrm{H}\right] \mathrm{DDF}$ in a carbamylcholine-sensitive manner belong to three distinct regions of the $\alpha$-subunit (Dennis et al. 1 986) that we will refer to as loops A, B and C (Fig. 2). They are identified as Tyr93 (loop A), Trp 49 (loop B), Tyr I 9o, and Cys 92 and I 93 (loop C), with in addition weakly labelled Trp86, Tyr I 5 , Tyrı98 (Dennis et al. I 988; 


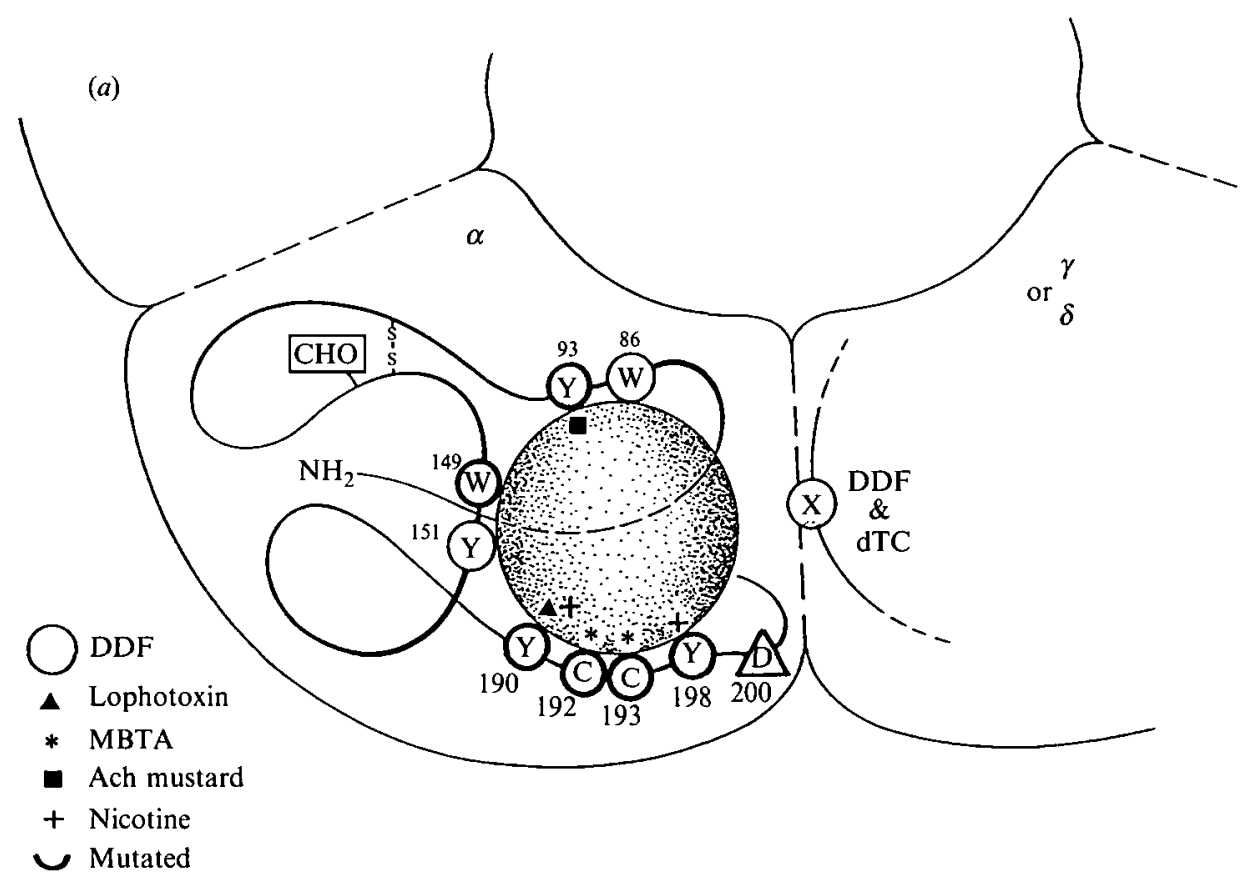

(b)

\begin{tabular}{|c|c|c|c|c|}
\hline \multirow{4}{*}{$\alpha}$. & \multirow{4}{*}{ Torpedo.. } & Loop A & Loop B & Loop C \\
\hline & & * & * & $\star \star *$ \\
\hline & & VWLPDLVLYNN. . & GIWTYDG. & VYYTCCPD-TPYLD \\
\hline & & $85 \quad 95$ & $147 \quad 153$ & $188 \quad 200$ \\
\hline $\begin{array}{l}\alpha_{1} \\
\alpha_{1}\end{array}$ & $\begin{array}{l}\text { human.... } \\
\text { cobra... }\end{array}$ & IWRPDLVLYNN . . & $\begin{array}{l}\text { GTWTYDG } \\
\text { GTWTYDG. }\end{array}$ & $\begin{array}{l}\text { VTYSCCPD-TPYLD } \\
\text { VNYSCCLD-TPYLD }\end{array}$ \\
\hline & & IWIPDIVLY & GSWTYDK & KKYD \\
\hline$\alpha_{3}$ & & IWKP & GSh & $-\underline{Q Q D}$ \\
\hline$\alpha \varepsilon$ & rat & IWRPDIVLYN & GSWTYDDK. & RKYECC-AEI-YYPD \\
\hline$\alpha_{7}$ & chick. & IWWRPDIVLYNN . & GSWTYYDK. & RKYECC-AEI-Y PD \\
\hline$\beta$ & Torpe & VWQPDIVLM & KSYTYYDT & ---- RSDDPSYED \\
\hline$y$ & Torpedo. & LWLPDVVLEI & RSQTY్NA. & NWQLTK-DDTDFQE \\
\hline & Torpedo. & VW̄I PDIVLQI & TALNȲDA. & - YPDKFPNGTNYQD \\
\hline & $F$ & IWWLPDVVLYNN. . & RSWTYYDR. & RRNEN-PDDSTYVD \\
\hline
\end{tabular}

Fig. 2. (a) A multiple loop model of the binding sites for nicotinic ligands: the sphere represents the DDF molecule in all possible orientations. Amino acids labelled by DDF, Lophotoxin, MBTA, Acetylcholine mustard and Nicotine are shown*. The residues labelled by d-tubocurarine (dTC) on the $\gamma$ - and $\delta$-subunits are Trp55 and Trp57 respectively (see text). (b) Comparison of the amino acid sequences from the $\mathrm{NH}_{2}$-terminal hydrophilic domain of several peripheral and central nicotinic receptor subunits showing the conservation of the DDF-labelled amino acids (modified from Galzi et al. I 991 a). * Bold symbols indicate mutated residues.

Galzi et al. 1990). Both $\alpha$-toxin and carbamylcholine decrease DDF labelling within the three regions in a parallel manner, supporting the conclusion that at least three loops (Figs 2,4) of the $\mathrm{NH}_{2}$-terminal large hydrophilic domain contribute to the nicotinic ligand-binding site.

These data are consistent with those of Kao et al. (1984) since DDF labels $\alpha$ - 
Cysi 92 and 193 (in the native receptor) which are also labelled by MBTA (after reduction of the protein). Moreover, $\alpha$-Tyri 90 , initially found labelled by DDF (Dennis et al. I988), covalently reacts with the coral competitive antagonist lophotoxin (Abramson et al. 1989). At equilibrium, nicotine labels $\alpha$-Tyri98, Cysig2 and Tyrigo (Middleton \& Cohen, I99I) which are all DDF-labelled amino acids (Dennis et al. 1988; Galzi et al. I990); $\alpha$-Tyr I90 is as well labelled by d-tubocurarine (Cohen et al. I99I) and the DDF-labelled $\alpha$-Tyr93 also incorporates acetylcholine mustard (Cohen et al. I99I). In other words photolabelling by energy transfer with DDF yields a pattern of amino acids which are (individually or by groups) also labelled by structurally distinct ligands of the nicotinic site.

Moreover, DDF-labelled amino acids are conserved (Fig. 2) at homologous positions in all $\alpha$-subunits from muscle and neuronal acetylcholine receptors [such as in $\alpha_{2}, \alpha_{3}, \alpha_{4}$ (references in Ochoa et al. I 992; Cockcroft et al. 1992)] from all species and tissues examined to date, including humans. An exception occurs in the sequence of the neuronal $\alpha_{5}$-subunit, which does not contain the amino acids homologous to Tyr93 and 190 and does not form functional acetylcholine receptor when expressed in Xenopus oocytes in association with any of the non- $\alpha$-subunits cloned (Boulter et al. 1990). None of the five predominantly labelled amino acids is conserved in $\beta$-, $\gamma$-, or $\delta$-subunits from electric organ or muscle. However, $\alpha$ Trpi 49 and $\alpha$-Tyr93 are both found at homologous positions in the non- $\alpha$ subunits from neuronal nicotinic receptors (references in Cockcroft et al. 1992), suggesting that these non- $\alpha$-subunits may have a function in neural tissue, distinct from those of the $\beta$-, $\gamma$-, and $\delta$-subunits in muscle and electric organ receptors. In any case, such high conservation of the affinity labelled amino acids through evolution is consistent with a physiological role of these amino acids in acetylcholine binding to the $\alpha$-subunits.

\section{I.3 Site directed mutagenesis of the amino acids identified by affinity labelling}

The functional significance of the chemically-labelled amino acids from the nicotinic-binding areas was further explored by site-directed mutagenesis and electrophysiological recordings in the Xenopus oocyte expression system. As mentioned, mutations of the MBTA and DDF-labelled Cysig2 and I93 into serines, interfere with $\alpha$-bungarotoxin binding and with the response to acetylcholine (Mishina et al. $\mathrm{I}_{985}$ ). Also, in the same domain mutation of Tyr 190 into Phe yields a receptor which requires more than 50 -fold higher concentration of acetylcholine for channel activation than wild type channels with the correlative decrease of agonist-binding affinity (Tomaselli et al. 1991).

The question remained, however, of the functional significance of the amino acids located in the two other domains. The amino acids corresponding to Torpedo Tyr93 (loop A), Trpi 49 (loop B) and Tyrigo (loop C) were thus mutated on the homooligomeric $\alpha 7$-subunit receptor from chick brain (Tyr92, Trpi 48 and Tyr $87, \alpha 7$ numbering) (Galzi et al. I 99 I $c$ ). All mutations significantly decreased the apparent affinities for acetylcholine and nicotine, but to a lesser extent those for the competitive antagonists dihydro- $\beta$-erythroidine $(\mathrm{DH} \beta \mathrm{E})$ and $\alpha$ - 
bungarotoxin. Other properties investigated like the voltage-dependency of the ion response as well as its sensitivity to the open channel blocker QX222 were not significantly changed, indicating that the mutations selectively affected the recognition of cholinergic ligands by the receptor protein. Mutations at nearby positions ( $\mathrm{S}_{94} \mathrm{~N}, \mathrm{~W}_{\mathrm{I}_{5}} \mathrm{~F}, \mathrm{G}_{\mathrm{I}_{5}} \mathrm{I}_{\mathrm{D}}$ and $\mathrm{G}_{22} \mathrm{E}$ ) did not affect the properties of the electrophysiological response. These data demonstrate the functional significance of Tyrg2, Trpi 48 and Tyri 87 in the binding of cholinergic ligands and ion channel activation of the $\alpha_{7}$ nicotinic receptor and bring strong support to the three-loop scheme of the nicotinic binding site (Galzi et al. I99 I c).

\section{I.4 Models of the nicotinic receptor site}

Classical models of the acetylcholine-binding site (as of the acetylcholinesterase catalytic site, see Nachmansohn, 1959) have assumed that carboxylate anions (side-chains of aspartic and glutamic acids) in the acetylcholine-binding site form a negative subsite responsible for the interaction with the cationic head-group of acetylcholine (reviewed in Luyten, 1986; Barnard et al. I987; Cockcroft et al. I992). In fact, neither glutamyl nor aspartyl residues were among the affinitylabelled residues identified. Orientation and/or reactivity restrictions of the affinity labelling reagents within the binding site may possibly lead to a preferential labelling of certain residues. On the other hand, these various chemicals, despite the fact that they react through different mechanisms become predominantly incorporated into aromatic amino acids, in particular Tyr and Trp. This finding is consistent with a model (Dennis et al. 1988; Galzi et al. 1990) in which aromatic rings would contribute to binding of the quaternary ammonium ligands. This aromatic basket model is consistent with the observation that binding of methyl-substituted ammonium groups by macrocyclic compounds requires not only electrostatic but also hydrophobic interactions (Dhaenens et al. 1 984). Both these interactions can be provided by strictly aromatic macrocycles (Schneider $e t$ al. 1986, 1988; Sheppod et al. 1986) and the presence of aromatic side chains in the binding sites for quaternary ammonium ligands appears to be a general property shared by several acetylcholine binding proteins, such as antiphosphorylcholine antibodies (Satow et al. I986), acetylcholinesterase (Sussman et al. I99I), muscarinic acetylcholine receptors (Hibert \& Trumpp-Kallmeyer, I99I; Wess et al. I99I) and also in potassium channel mutants which bind tetraethyl ammonium (Heginbotham \& McKinnon, r 992).

This conclusion does not exclude that other amino acid side chains from the acetylcholine-binding domain may also play critical roles in signal transduction (Gross et al. I 99 I). Indeed, mutation of the highly conserved aspartate residue at position 200 on Torpedo $\alpha$-subunit (Figs 2, 4), converts partial agonists (phenyltrimethyl ammonium or tetramethyl ammonium) of the wild type receptor into competitive antagonists, without significantly decreasing the apparent affinity for acetylcholine (O'Leary \& White, I 99I). This still preliminary observation points to a carboxylate anion, which in agreement with the above model, does not seem directly involved in the binding of nicotinic ligands. Rather, its mutation would plausibly interfere with the coupling between agonist binding and channel 


\begin{tabular}{|c|c|c|c|}
\hline & Loop A & Loop B & Loop C \\
\hline & $84 *$ & $* * 154$ & $185 * * * 209$ \\
\hline $\mathrm{nACH} \alpha$ & DVWLPDLVLXNNAD & CEIIVTHFPFDQQNCTMKLGIHTYDGT & KHWVYYTCCPD-TPYLDITYHFIMQR \\
\hline $\mathrm{nACH} \beta$ & DVWQPDIVLMNAND & CTIKVMYFPFDWQNCTMVFKYTYDTS & KNW----RSDDPSYEDVTFYLI IQR \\
\hline $\mathrm{nACH} \gamma$ & LLWLPDVVLENNVD & CPIAVTYFPFDWQNCSLVFRSQTYNAH & KNYNWQLTK-DDTDFQEIIFFLIIQR \\
\hline $\mathrm{nACH} \delta$ & LVWIPDIVLQNNND & CPINVLYFPFDWQNCSLKFTALNYDAN & KNI-YGDKF PNGTNYQDVTFYLIIRR \\
\hline nACH 07 & LIWKEDILLYNSAD & CYIDVRWFPFDWQKCNLKFGSWTYGGW & KRTESFYECCK-EPYPDITFTVTMRR \\
\hline GABA $\alpha$ & KIWTEDTFFHNGKK & CPMHLEDF PMDAHACPLKFGSYAYTRA & TVD-SGIVQSSTGEYVVMTTHFHLKR \\
\hline GABA $\beta$ & QLWVPDTYFLNDKK & CMMDLRRYPLDEQNCTLEIESYGYTTD & KMV-SKKVEFTTGAYPRLSLSFRLKR \\
\hline GABA $\gamma 2$ & KIWI PDTFFRNSKR & CQLQLHNF PMDEHSCPLEFSSYGYPRE & RNTTEVVKTTS-GDYVVMSVYFDLSR \\
\hline GABA $\delta$ & KLWLPDTFIVNAKV & CDMDLAKYPMDEQECMLDLESYGYSSE & RFTTELMNFKSAGQF PRLSLHFQLRR \\
\hline GLY $\alpha_{2}$ & SIWKPDLFFANEKG & CPMDLKNF PMDVQTCIMQLESFGYTMN & KELGYCTKHYNTGKFTCIEVKFHLER \\
\hline GLY hal & SIWKEDLFFANEKG & CPMDLKNF PMDVQTCIMQLESFGYTMN & KDLRYCTKHYNTGKFTCIEARFHLER \\
\hline GLY ha2 & SIWKPDLFFANEKG & CPMDLKNFPMDVQTCTMQLESFGYTMN & KELGYCTKHYNTGKFTCIEVKFHLER \\
\hline GLY $\beta$ & CLWKPDLFFANEKS & CPLDLTLFPMDTORCKMQLESFGYTTD & IEYGNCTKYYKGTGYYTCVEVIFTLR \\
\hline $5 \mathrm{HT}_{3}$ & SIWVRDILINEFVD & CSLDIYNFPFDVQNCSLTFTSVLHTIQ & PQFKEFSIDIS-NSYAEMKFYVIIRR \\
\hline
\end{tabular}

Fig. 3. Comparison of amino acid sequences from loops $\mathrm{A}, \mathrm{B}$ and $\mathrm{C}$ from the $\mathrm{NH}_{2}$-terminal hydrophilic domain of the nicotinic, $\mathrm{GABA}_{\mathrm{A}}$, Glycine and ${ }_{5} \mathrm{HT}_{3}$ receptors showing the occurrence of conserved canonic amino acids located in the vicinity of the DDF-labelled amino acids in Torpedo nicotinic receptor (modified from Galzi et al. 199 $b$ ). Amino acids involved in benzodiazepine (GABA $\alpha$ ) and strychnine (Gly $\alpha_{2}$ and Gly h $\alpha_{1}$ ) binding are underlined.

opening and/or alter the difference of pharmacological properties of the cholinergic site in the resting and active conformations of the receptor.

Moreover, the contribution of the non- $\alpha$-subunits to the organization of the nicotinic ligand-binding area is still largely unexplored. Attempts to identify amino acids from the non- $\alpha$-subunits in Torpedo receptor have been reported with $\mathrm{S}-\left(2-\left[{ }^{3} \mathrm{H}\right]\right.$ glycylamidoethyl $)$ dithio-2-pyridine. This ligand, which reacts with the mildly reduced protein, labels a predominant site on the $\delta$-subunit located between amino acids I 64 and 257 (Czajkowski \& Karlin, I 99 I). Another group has also reported that d-tubocurarine is primarily incorporated into Trp residues 55 and 57, on the $\gamma$ - and $\delta$-subunits respectively (Cohen et al. I992, Fig. 4).

Beside the Cys I92-I 93 doublet conserved in the receptor $\alpha$-subunit sequences, two additional cysteine residues forming a Cys-loop (Cys 28 and Cysi42 in Torpedo $\alpha$-subunit) are found at homologous positions in all nicotinic receptor subunits as in $\mathrm{GABA}_{\mathrm{A}}$ and glycine receptors (Fig. 3). These residues have been proposed to form a disulphide bridge in vivo, and their mutation to serine residues totally abolishes the response to acetylcholine (Mishina et al. 1985). They are most probably involved in the tertiary folding of the large amino terminal domain exposed to the synaptic cleft and model for the agonist site common to all ligandgated ion channels has been suggested on this basis (Cockcroft et al. I 990, I 992). This particular model strictly relies upon the amphiphilic $\beta$-hairpin structure of the Cys-loop. Yet, to date none of the affinity-labelled residues identified with the nicotinic receptor has been found within this loop. On the other hand, mutation of Asp 1 48, which lies within this loop in human Gly $\alpha_{1}$-subunit, interferes with the response to the neurotransmitter (Vandenberg et al. 1992a,b). 


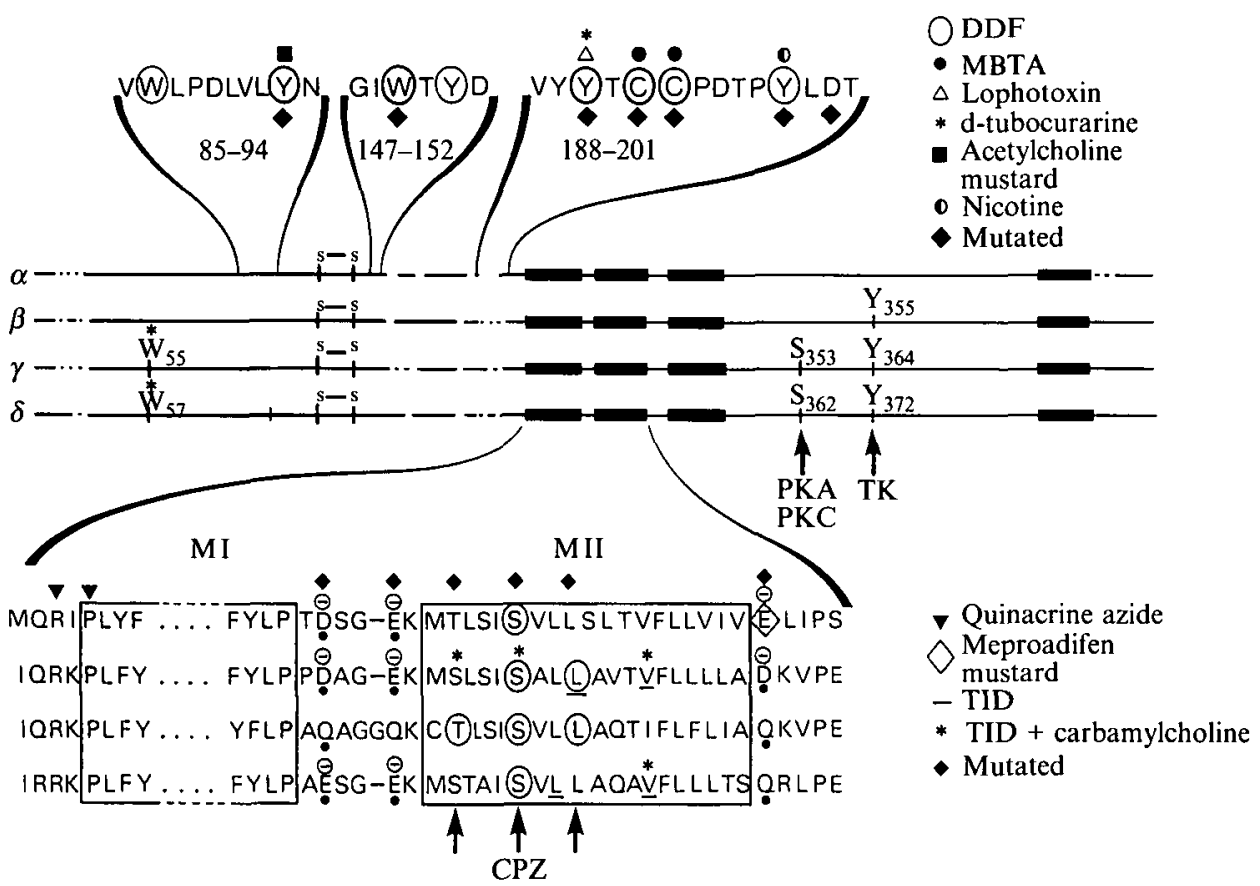

Fig. 4. Amino acids chemically labelled or mutated in the cholinergic binding area and channel domain of the four subunits of Torpedo receptor are depicted. Sites of phosphorylation by protein kinase A (PKA), C (PKC) and tyrosine kinase (TK) are shown (references in the text).

On the basis of the homologies existing between the known neurotransmittergated ion channels, a more general view for the neurotransmitter-binding area emerges (see Galzi et al. I99 I b, Fig. 3). It relies on the presence of strictly conserved 'canonical' amino acids for $\mathrm{GABA}_{\mathrm{A}}$, Gly, and ${ }_{5} \mathrm{HT}_{3}$ receptors (Maricq et al. I99I) and all nicotinic acetylcholine receptors and extends the three-loop scheme of the nicotinic ligand-binding area to these ligand-gated ion channels (the case of glutamate receptors will be dealt with separately). For instance, the loop $A$ that contains the DDF-labelled $\alpha$-Tyr93, contains the canonical amino acids $\alpha$ $\operatorname{Trp} 86, \alpha-\operatorname{Pro} 88, \alpha-A s p 89$ and $\alpha$-Asn94. Another DDF-labelled amino acid $\alpha$ Trpi 49 tags loop $B$ which is located in the vicinity (but not within) the canonical Cys-loop and $\alpha$-Tyr I 5 I. Interestingly, comparison of neonate and adult receptor (Becker et al. 1988), and site-directed mutagenesis (Kuhse et al. I990; Vandenberg et al. I $992 a, b$ ) of the Gly $\alpha_{1}$-subunit points to the role of Gly 160 and Tyri6I (from human receptor and homologs in rat) in the binding of the competitive antagonist strychnine. Finally, loop $C$, which includes $\alpha$-Tyrigo and $\alpha$-Cysig2-193 in the nicotinic receptor is located ahead of the DDF labelled 'canonical' aromatic amino acid $\alpha$-Tyri 98 . Loop $\mathrm{C}$ appears highly variable in nicotinic non- $\alpha$-subunit as in $\mathrm{GABA}_{\mathrm{A}}$, glycine and ${ }_{5} \mathrm{HT}_{3}$ receptors. On the other hand, mutation of Gly 200 in rat $\alpha_{I}-G_{A B A}$ subunit (the homologue of DDFlabelled Tyr I90) within this loop, strikingly modifies the effect of benzodiazepine on GABA response (Pritchett \& Seeburg, I99I); also mutation of Lys2oo and 
Tyrzo2 in human glycine receptor interferes with strychnine binding (Vandenberg et al. $1992 a, b$ ). The amino acid side-chains from the highly variable loop $\mathrm{C}$ are thus expected to be more directly concerned than loops $\mathrm{A}$ and $\mathrm{B}$ by the actual bonding with groups which characterize the specific structure of the pharmacological ligands. On the other hand, altogether loops A, B, and C may adopt main chain backbone structures common to all mentioned ligand-gated ion channels. The tertiary folding of the ligand-binding domain of the different members of this superfamily would then follow a common scheme.

\section{IDENTIFICATION AND MAPPING OF THE ION CHANNEL}

\section{I Affinity labelling by non-competitive blockers}

As in the case of the acetylcholine binding area, affinity labelling played a decisive role in the identification of the amino acids which border the ion channel (for review, see Changeux, 1990). It relied upon the use of pharmacological agents known as non-competitive blockers which, in contrast to curare and curare-like agents, do not significantly interact with the acetylcholine-binding site (Adams, I 98 I ; Heidmann et al. I $983 a$ ). Biophysical analysis of their mode of action led to the proposal that some of them may sterically inhibit the transport of ions by entering the channel (from either side of the membrane) and by binding to a common site located within the ion channel (Neher \& Steinbach, 1978; Changeux et al. I 986; Rapier et al. I 987; Ramoa et al. 1990). They include pharmacological agents such as local anaesthetics (tetracaine, prilocaine, trimethisoquin), the neuroleptic chlorpromazine, the hallucinogen phencyclidine, the frog toxin histrionicotoxin and several synthetic compounds like QX222. Several of them not only block muscle and neuronal nicotinic receptor ionic permeability but also that of $N$-methyl-D-aspartate receptor (Albuquerque et al. I988) suggesting that the concept of a receptor superfamily with common principles of functional architecture also applies to the ion channel (see following paragraphs; Changeux, I 990; Galzi et al. I 99 I $a$; Cockcroft et al. I 992).

Equilibrium binding studies carried out with Torpedo marmorata receptor and several noncompetitive blockers, including local anaesthetics, chlorpromazine, phencyclidine, histrionicotoxin and meproadifen (Weber \& Changeux, 1974c; Cohen et al. 1974; Changeux, I990), revealed two main categories of sites, distinct from the acetylcholine-binding site (Heidmann et al. I983a) : a high-affinity site, sensitive to histrionicotoxin and present as a single copy per $2 \alpha \beta \gamma \delta$ oligomer, and low-affinity sites which are insensitive to this toxin but present in larger number ( I $0-30$ per receptor molecule) and possibly located at the lipid-receptor interface. The demonstration that the four different subunits contribute to the unique highaffinity site [to an extent that varies with the compound and the species (Galzi et al. I $99 \mathrm{I} a)$ ] led to the proposal that this site lies in the axis of pseudosymmetry of the receptor (Heidmann et al. I983a, Fig. I). Its location would then resemble the binding site for 2,3-diphosphoglycerate (and some anti-sickling drugs) in haemoglobin (Perutz, I 989).

Evidence from in vitro experiments brought support to the view that this site lies within the ion channel (Heidmann et al. I983a): (1) chlorpromazine causes, 
under defined conditions, reduction of the mean channel open time (Changeux $e t$ al. 1986; P. Benoit, unpublished observations); also permeant cations inhibit in a competitive manner the binding of non-competitive blockers, ethidium or phencyclidine, to their high-affinity site (Herz et al. I989 and Revah, unpublished); (2) rapid-photolabelling experiments with chlorpromazine (Heidmann \& Changeux, I 984 , 1986) show that its rate of covalent attachment to the high-affinity site increases $10^{2}-10^{3}$-fold upon mixing with acetylcholine, with a time-course characteristic of the opening of a population of ligand-gated channels rapidly exposed to a constant concentration of acetylcholine; under these conditions, the apparent $K_{\mathrm{d}}$ for acetylcholine (about $30 \mu \mathrm{M}$ ) is close to that required for the activation of the ion channel both in vivo and in vitro on the same membrane preparations, and the competitive antagonists d-tubocurarine or the $\alpha$ toxins block the response; (3) the rate of chlorpromazine incorporation declines upon pre-exposure to a constant concentration of acetylcholine, with kinetics (Heidmann \& Changeux, I986) close to those measured for the rapid desensitization of the ion flux response (Hess et al. 1982; Walker et al. 1982). Though the kinetics of covalent attachment of other noncompetitive blockers might differ quantitatively (Muhn et al. 1984; Fahr et al. I985; Cox et al. 1985), the characteristics of this rapid labelling process support the notion that, under the conditions tested, $\left[{ }^{3} \mathrm{H}\right]$ chlorpromazine binds to its high-affinity site without restriction to diffusion, and covalently reacts with this site while the channel opens (Heidmann \& Changeux, 1984, 1986).

\subsection{The MII segment is a component of the ion channel}

The amino acid photolabelled by $\left[{ }^{3} \mathrm{H}\right]$ chlorpromazine under equilibrium conditions with Torpedo acetylcholine receptor-rich membranes was initially identified by peptide mapping and sequencing experiments on the $\delta$-subunit as Ser262 (Giraudat et al. 1986; Fig. 4). Labelling of $\delta$-Ser262 is blocked by phencyclidine and belongs to the hydrophobic segment MII, thus pointing to MII as part of (or in the close vicinity to) the high-affinity site for non-competitive blockers within the ion channel (Giraudat et al. I 986). Similar experiments were repeated with the other subunits and sequence analysis resulted in the identification of Ser254 and Leu257 for the $\beta$-subunit (Giraudat et al. 1987), Ser24 8 for the $\alpha$-subunit (Giraudat et al. ${ }_{1989}$ ) and Thr253, Ser257 and Leu260 for the $\gamma$-subunit (Revah et al. I 990) as residues labelled by $\left[{ }^{3} \mathrm{H}\right]$ chlorpromazine in a phencyclidine sensitive manner. Following the finding of Giraudat et al. ( I 986) with chlorpromazine, Oberthür et al. (I986) using triphenylmethylphosphonium (TPMP) have also identified $\delta$-Ser 262 as the labelled amino acid. In another report, Hucho et al. (I 986) have obtained fragmentary evidence that also points to Ser248 and Ser254 as the amino acids labelled by TPMP on the $\alpha$-and $\beta$-subunits, respectively.

The affinity-labelling data obtained with $\left[{ }^{3} \mathrm{H}\right]$ chlorpromazine (Giraudat et al. I 986, I 987, I 989; Revah et al. I 990) and TPMP (Hucho et al. I 986 ; Oberthür et al. 1986), thus support the view that: (1) homologous regions of different receptor subunits contribute to the unique high-affinity site for non-competitive blockers 
Cleft

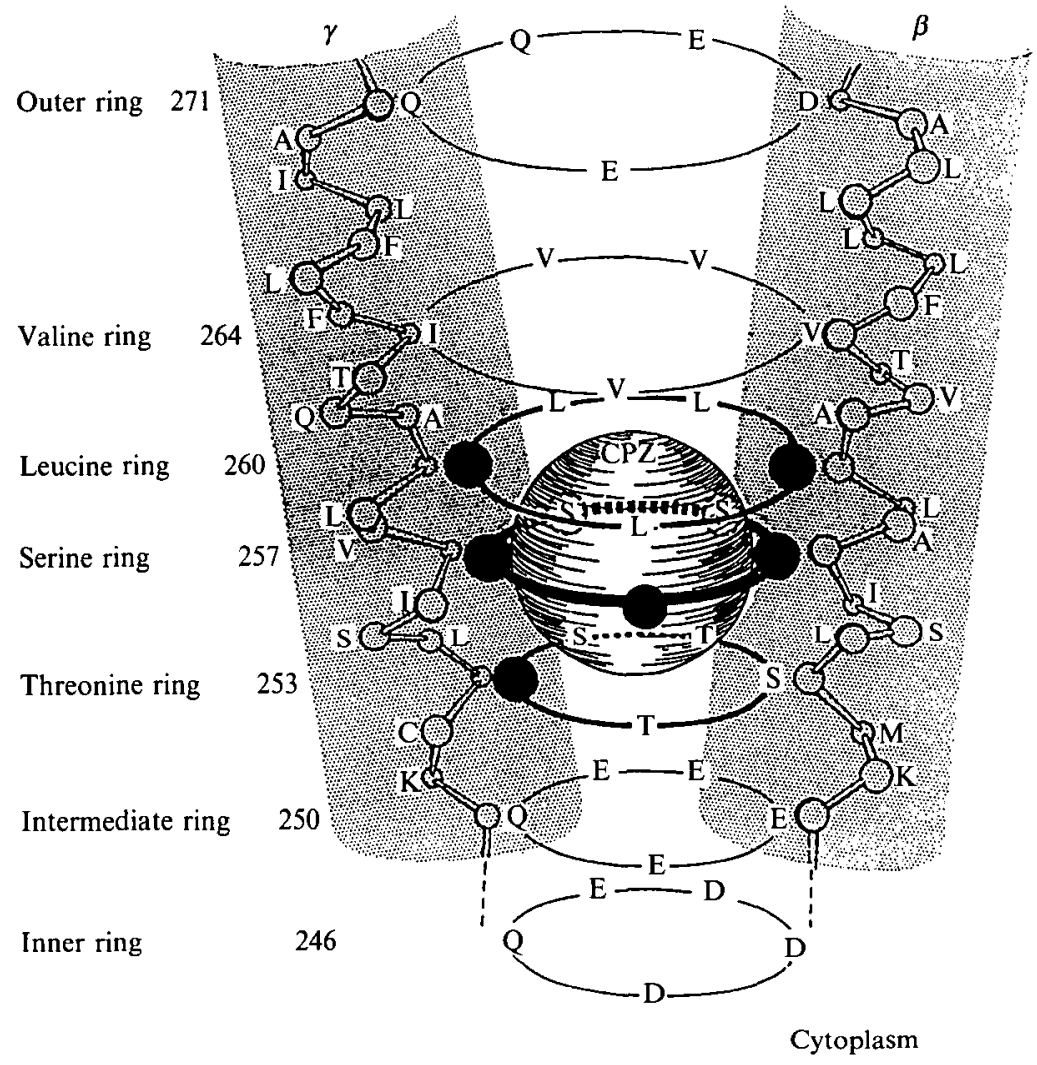

AChR

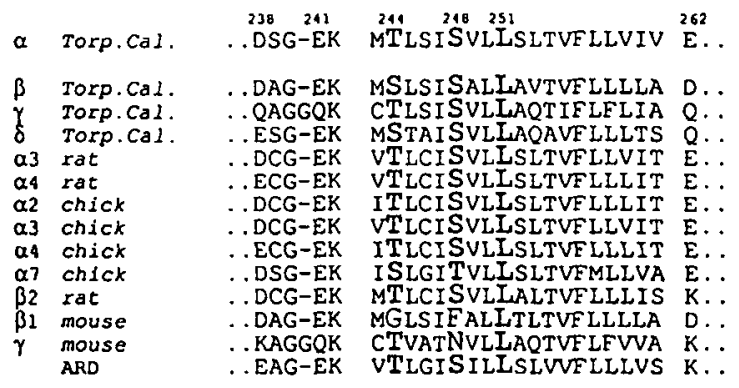

Gly $R$

\begin{tabular}{|c|c|c|}
\hline$\frac{\alpha 1}{\beta}, \alpha 2 *$ & $\begin{array}{l}\text {. DAAPAR } \\
\text {.DAAPAR } \\
\ldots \text { DASAAR }\end{array}$ & $\begin{array}{l}\text { VGLGITTVLTMTTQSSGSR } \\
\text { VALGITTVLTMTTQSSGSR } \\
\text { VPLGIESVLSLASECTTLA }\end{array}$ \\
\hline$A_{B} A_{A} R$ & & \\
\hline $\begin{array}{l}\alpha_{1}, \alpha_{2}, \alpha 5 \\
\alpha_{3}\end{array}$ & $\begin{array}{l}\ldots \text { ESVPAR } \\
\ldots \text { ESVPAR } \\
\ldots \text { ESVPAR } \\
\ldots \text { ESVPAR } \\
\ldots \text { DASAAR } \\
\ldots \text { DASAAR } \\
\ldots \text { DAVPAR } \\
\ldots \text { AAVPAR }\end{array}$ & $\begin{array}{l}\text { TVFGVTTVLTMTTLS ISAR } \\
\text { TVEGVTTVITMTTLS ISAR } \\
\text { TVEGVTTVLTMTTLS ISAR } \\
\text { TVEGITTVITMTTLSISAR } \\
\text { VALGITTVLTMTT I STHLR } \\
\text { VALGITTVLTMTT INTHLR } \\
\text { TSLGITTVITMTTLST IAR } \\
\text { VSLGITTVITMTTLMVSAR }\end{array}$ \\
\hline
\end{tabular}

Fig. 5. 
within the ion channel, a finding consistent with the proposal (Heidmann et al. I $983 a$ ) that this site is located in the axis of pseudo-symmetry of the receptor molecule; and (2) chlorpromazine and TPMP are found to label three 'rings' of amino acids which are located at three to four amino acids distance from each other and referred to as 'threonine', 'serine', and 'leucine' rings (from the $\mathrm{NH}_{2}$ to $\mathrm{COOH}$ end of MII, see Fig. 5); such disposition supports an organization of MII into an $\alpha$-helix, the $\alpha$-carbons of the labelled amino acids being aligned on the same meridian on adjacent turns of the helix (Giraudat et al. 1987; Revah et al. I 990).

Pedersen \& Cohen (1990 b) have used another noncompetitive blocker, a mustard derivative of meproadifen to affinity label the $\alpha$-subunit amino acid Glu262, an amino acid belonging to the 'outer ring of negatively charged residues' (Figs 4, 5 and see below) located at the border of the MII segment in the region linking MII and MIII. This labelling might result from reversible binding to the same high-affinity site as chlorpromazine (Heidmann et al. r983a) but with covalent reaction with the closest available nucleophilic amino acids. In another report, Cohen and co-workers, using 3-(trifluoromethyl)-3-m$\left(\left[{ }^{125} \mathrm{I}\right]\right.$ iodophenyl)diazirine (TID) as a photoaffinity ligand, have shown that this noncompetitive blocker labels amino acids from the MII segment but with different relative efficiency after equilibration with carbamylcholine or in its absence (White et al. I 99 I ; White $\&$ Cohen, I 992). In the absence of agonist, TID labels a residue from the Leu ring on Torpedo $\beta$-subunit and an additional residue $\beta$-Val26 I pointing to the contribution of a 'valine' ring to the binding site of 'TID (Figs 4,5 ). On the $\delta$-subunit the homologues in the Leu and Val rings are labelled. In the presence of agonists, labelling of these residues is reduced by $90 \%$ and the distribution of the labelled residues is broadened to include residues at the chlorpromazine labelled 'threonine' and 'serine' rings. In the $\beta$-subunit, residues from the Thr, Ser and Leu rings are all labelled in the presence of carbamylcholine (White et al. I 99 I ; Cohen et al. 1992). In other words, the recent data of Cohen and coworkers confirm and extend those obtained with chlorpromazine and TPMP.

Moreover, the distance between the nicotinic receptor site and the high-affinity site for non-competitive blockers [explored by energy transfer with dansyl C6 choline (Waksman et al. 1980) as a fluorescence 'donor' and ethidium bromide as an energy 'acceptor' (Herz et al. I 989)] ranges between $2 \mathrm{I}$ and $35 \AA$. This is close to the distance between haems in haemoglobin, and between regulatory and catalytic sites in regulatory enzymes (Perutz, 1989). The positive interaction between the acetylcholine-binding sites and the high-affinity site for noncompetitive blockers thus takes place between topographically distinct (and distant) sites typically as in allosteric proteins.

Fig. 5. Model of the high affinity site for noncompetitive blockers within the ion channel (amino acids numbering on the left refers to Torpedo $\gamma$-subunit) (modified from Revah $e t$ al. I 990) and comparison of the amino acid sequence from the MII segment from several ligand-gated ion channels. Seven rings of homologous amino acids are shown. 


\subsection{Exploration of MII function by site directed mutagenesis}

The contribution of segment MII to the ion channel initially revealed by affinity labelling (Giraudat et al. I 986; Hucho et al. 1986), soon received support from electrophysiological experiments carried out with acetylcholine receptor channels expressed in Xenopus oocytes (Imoto et al. 1986). Receptor proteins of $T$. californica and calf exhibit different intrinsic ion channel conductances (Sakmann et al. 1 985). On this basis, the domain of the receptor $\delta$-subunit responsible for the observed differences in conductance was identified by constructing various chimeric $\delta$-subunit mRNAs from Torpedo and calf expressed together with wild type $\alpha$-, $\beta$ - and $\gamma$-subunits (Imoto et al. I 986). The data suggested that 'MII and the segment located between MII and MIII' were involved in determining the conductance difference noted between Torpedo and calf channel (Imoto et al. I 986 ).

In a later study (Imoto et al. I988) point mutations were introduced into the receptor subunit cDNAs of Torpedo to alter 'three rings of negatively charged or glutamine residues' inner $(\gamma$-Gln246), intermediate $(\gamma-\mathrm{G} \ln 250)$ and outer $(\gamma$-Gln27I) rings located on either side of the MII segment (Fig. 5). Under conditions of low divalent ion concentration, these mutations were accompanied by changes of channel conductance for monovalent cations. Despite the fact that under more physiological conditions (presence of divalent cations), several of these mutations might not be accompanied by significant changes of channel properties (Imoto et al. I 986), these studies brought useful information about the topology of the channel. A sidedness of $\mathrm{Mg}^{2+}$ effects was noticed and from this, the anionic ring between MII and MIII ( $\gamma$-Gln27I and homologues) was located on the extracellular side, the two others between MI and MII ( $\gamma$-Gln246 and homologues) and ( $\gamma$-Gln250 and homologues), on the cytoplasmic side. As suggested by all models of transmembrane folding of the subunits, the segment MII thus spans the membrane. The results of these mutagenesis experiments are thus consistent with the proposed location of $\left[{ }^{3} \mathrm{H}\right]$ chlorpromazine, TPMP and TID binding sites which would be 'framed' by these anionic rings within the membrane (Giraudat et al. I987; Hucho et al. 1986).

Recently, the intermediate ring has been claimed to 'represent part of the physical correlate of the postulated selectivity filter in the acetylcholine receptor channel' (Konno et al. I 99 I). Mutations in this ring indeed affect the conductance for $\mathrm{Rb}^{+}$and $\mathrm{Cs}^{+}$ions (Konno et al. I99I ; Imoto et al. I991), yet, without changing the permeability preference for the physiological ions $\mathrm{K}^{+}>\mathrm{Na}^{+}>\mathrm{Li}^{+}$. Further studies are thus needed to understand the mechanism of ion selectivity, in particular the structure which governs anion versus cation selectivity.

In parallel, the physiological role of the rings of uncharged amino acids labelled by chlorpromazine (and/or TID) was investigated by site-directed mutagenesis. Mutation into Ala of residues from the Ser ring of mouse muscle receptor causes selective decrease in outward single-channel currents and in residence time (and thus of the affinity) of the channel blocker QX222 (Leonard et al. I 988). Mutation of mouse receptor residues homologous to Torpedo $\gamma$-Alaz6I (one amino acid 


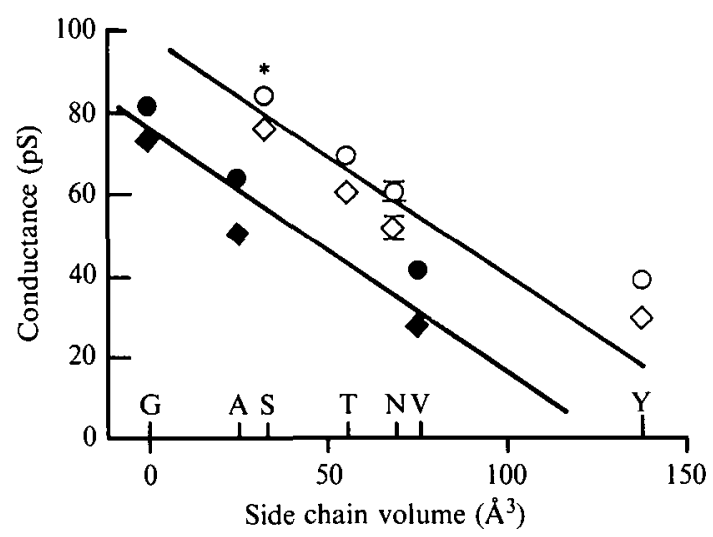

Fig. 6. Comparison of the effect of different mutations at the level of the 'threonine ring' in the $\delta$-subunit suggesting a 'catalytic' role of polar residues within the ion channel (redrawn from Imoto et al. 1991). At a constant side chain volume hydrophilic or polar residues (open symbols) systematically yield higher conductance ( $-100 \mathrm{mV}$ : circles; $+100 \mathrm{mV}$ : diamonds) than hydrophobic ones (closed symbols). The star denotes the wild type residue in this subunit. Mutations in the $\alpha$-, $\beta$ - and $\gamma$-subunits yield similar results (see Imoto et al. I99I) to those of the $\delta$-subunit.

distant from the 'leucine ring') also yielded changes in the residence time of QX222 (Charnet et al. 1990). Mutation into Val of residues from the chlorpromazine labelled Threonine ring (Villarroel et al. I99 I for rat receptor; Imoto et al. I99 I for T. californica receptor), caused a slight decrease (about $20 \%$ ) of the conductance for $\mathrm{K}^{+}$, whereas its replacement by Ala or Gly slightly increased it (by about 10\%).

In a more general manner, replacement of residues from the 'threonine ring' with hydrophobic (Gly, Ala or Val) or polar side-chains (Ser, Thr, Asn and Tyr) with different volumes revealed a systematic trend. For a given volume, polar side-chains systematically yield higher conductances than the hydrophobic ones (Imoto et al. I991, Fig. 6). This observation gives credence to the view that their mild electronegative character may by trapping the water molecules and reducing the size of the permeant ion facilitate or even 'catalyze' ion translocation through the channel (Changeux, I990, Fig. 6).

Comparison of MII sequences between nicotinic, glycine, ${ }_{5} \mathrm{HT}_{3}$ and $\mathrm{GABA}_{\mathrm{A}}$ receptors reveal a striking conservation of some of the amino acid rings mentioned above (Fig. 5).

The amino acids from the inner and outer rings are conserved (as Asp, Glu and/or Gln) at homologous positions in all known nicotinic and ${ }_{5} \mathrm{H}^{\mathrm{T}} \mathrm{H}_{3}$ receptor subunits as well as in the $\mathrm{GABA}_{\mathrm{A}}$ and Gly receptors where the transported ion is negatively charged. Even though another alignment may be found, the outer and inner rings seem to be more directly involved in the regulation of ion access to the channel than in determining its transport selectivity.

The strongest effects on conductance and selectivity have been reported to take place after mutation of the 'intermediate ring' (Imoto et al. I988; Konno et al. I99I). This negatively charged ring is indeed conserved in all neuronal nicotinic 
receptors but absent from $\mathrm{GABA}_{\mathrm{A}}$ or Gly receptors where it is replaced by either an Ala or Arg ring, depending on the alignment.

Interestingly, the chlorpromazine-labelled Ser ring is conserved through all neuronal nicotinic receptor subunits and exchanged with a ring of $\mathrm{Thr}$ in all known Gly, GABA ${ }_{\mathrm{A}}$ and ${ }_{5} \mathrm{HT}_{3}$ receptor subunits (see Fig. 5). On the other hand, the chlorpromazine-labelled 'Thr ring is either conserved or replaced by a Ser ring in most (not all) nicotinic receptor subunits. A Ser is present at the homologous position in the ${ }_{5} \mathrm{HT}_{3}$ and in the $\gamma 2$ - and $\delta-\mathrm{GABA}_{\mathrm{A}}$ receptor subunits but replaced by various hydrophobic amino acids (Val, Ala, Pro, Gly) in the known GABA $_{A}$ and in the glycine receptors.

The chlorpromazine-labelled Leu ring is conserved in all known subunits of nicotinic, glycine, $\mathrm{GABA}_{\mathrm{A}}$ and $5 \mathrm{HT}_{3}$ receptors investigated. The functional significance of this canonical amino acid will be discussed in the next section.

In conclusion, the high conservation of critical amino acids within MII noticed in the known members of the superfamily of ligand-gated ion channels strengthens the view that: (I) the hydrophobic segments MII serves as a critical component of the ion channel in all these receptors; and (2) despite their difference in ion selectivity, these ionic channels display a similar (or closely related) organization.

On the basis of this information, various theoretical models of the ion channel have been suggested (see Pullman, I99 I Eisemann \& Alvarez, I99 I, for review).

\section{ALLOSTERIC INTERACTIONS BETWEEN THE NICOTINIC RECEPTOR SITES AND THE ION CHANNEL}

\section{I Activation of the ion channel}

Early, ion flux measurement with purified membranes from Electrophorus (Kasai \& Changeux, 1970, 1971) and Torpedo (Hazelbauer \& Changeux, 1974; Popot et al. 1974) revealed that, in agreement with the hyposthesis that the receptorchannel complex is a membrane-bound allosteric protein, its activation does not require addition of energy, beyond the increased chemical potential of acetylcholine. Moreover, the positive interaction between the acetylcholinebinding area and the site for non-competitive channel blockers takes place, as mentioned, between topographically distant sites. As a consequence, the opening of the ion channel by acetylcholine, cannot result from 'direct' effects, but, rather, from indirect or 'allosteric' interactions in their original sense (Monod et al. 1963). Accordingly, a fast conformational change is expected to account for the 'activation' of the ion channel by acetylcholine.

Two possibilities at least may be envisioned for such allosteric process: an 'induction' of the conformational change by the nicotinic agonist 'adapted' to the particular structure of the agonist or the 'stabilization' of one of few (at least two) states presumed to exist in reversible equilibrium before the interaction with the ligand. Two series of observations favour the second possibility: ( $\mathrm{I}$ ) the resolution by the patch-clamp technique of the response to acetylcholine into single all-ornone openings and closings of the nicotinic receptor channel with an elementary 
conductance independent of the particular structure of the agonist (Katz \& Miledi, I973 $b$; Colquhoun, I979; Colquhoun \& Sakmann, I985) and (2) the occurrence, in some systems and at a low frequency, of spontaneous openings of the ion channel which are blocked by $\alpha$-bungarotoxin (Jackson, r 984, I988, r989). Accordingly, the equilibrium between closed and open states would be spontaneously displaced (in the absence of agonist), in favour of the resting closed state.

The fast conformational transition which accounts for the rapid opening of the ion channel has not yet been resolved by physico-chemical techniques down to the amino-acid level. Strictly theoretical work on bundles of five helices including hydrophilic amino acids at the interface has led to the proposal of several modes of packing for such pentagonal prisms (Furois-Corbin \& Pullman, I 988; Pullman, I991). Energy minimization calculations suggest four quite stable structures, similar in energy, where the relative positions of the helices are significantly different. 'These calculations illustrate how the size and shape of an axial 'channel' could be modulated by tilting and/or sliding of the helices during 'asymmetrical' transitions of the pentameric bundle. The analogy with the acetylcholine receptor is not straightforward since the $\alpha$-helices in these model bundles point in opposite directions around the 'channel'. In contrast, in the natural receptor such disposition may exist within a subunit, but not around the walls of the channel which are assumed to be made up of parallel homologous helices. Nevertheless, these models allow asymmetrical motions of rigid $\alpha$-helices within receptor subunits as documented in globular proteins (Chothia \& Lesk, r985; Perutz, I 989).

Several, still hypothetical, schemes may be envisioned for the all-or-none opening of the ion channel and for the homotropic cooperativity between acetylcholine binding sites assuming a 'concerted' transition of quasi-symmetrical organization of the receptor pentamer: (a) global all-or-none 'twist' of the molecule (see Unwin \& Zampighi, I980; Furois-Corbin \& Pullman, 1988) according to which the five transmembrane subunits would rigidly tilt tangentially to the axis of quasi-symmetry of the molecule thereby changing the diameter of the central cavity [according to Stroud et al. (1990), such helix twisting, however, may not regulate the physical diameter of the pore to a sufficient extent to be physiologically significant]; $(b)$ global all-or-none 'bloom' of the molecule which would consist of an opening- or closing-up of the molecule (like an umbrella), the 'bottom' of the molecule remaining fixed at the interface with the cytoplasm (Changeux, I 990).

Models where the rigidity of some critical $\alpha$-helices may be disrupted within the receptor molecule have also been considered. 'Hemi-twist or-bloom ' models may be imagined where the opening (closing) of the channel (determined by the upper part) could be dissociated from its ionic selectivity (see Changeux, I 980). Interestingly, a striking feature of the MI segment is that it contains a highly conserved proline residue in acetylcholine, Gly, and $\mathrm{GABA}_{\mathrm{A}}$ (and possibly kainate) receptors. Since prolines cannot form hydrogen bonds, the structure of helical rods is disrupted. Their presence in transmembrane domains has been 
proposed to provide flexibility to otherwise relatively rigid structures (Campbell, I 988; Brandl \& Deber, I986). Yet, at this stage, the demonstration that these particular proline residues contribute to the gating of the ion channel remains to be tested.

Finally, even if they do not account for several characteristic features of the acetylcholine receptor, one should mention the possibility that local subunit changes may take place which are not transmitted to the rest of the quaternary structure. Additional information on the three-dimensional organization of the receptor molecule is needed to distinguish between these possibilities.

\subsection{Regulation by desensitization of the permeability response to nicotinic agonists}

(a) Analysis of desensitization in vitro

Prolonged exposure of muscle, electroplaque and brain nicotinic acetylcholine receptor to agonists causes, within seconds to minutes, a reversible decline in the ionic response to acetylcholine (Katz \& Thesleff, I957, Changeux, I980; Ochoa et al. I 989, I 992). Desensitization persists after purification of excitable membranes (Popot et al. 1974) and after reconstitution of the purified protein (Popot et al. I98I; McNamee \& Ochoa, I982; Montal et al. I986). It is thus an intrinsic property of the $2 \alpha \beta \gamma \delta$ oligomer. It consists of two kinetically distinct processes with respective rates of $2-75$ and $0^{\circ} \mathrm{OI}_{-} \mathrm{O}^{\circ} \mathrm{I}$ per second (Changeux et al. I 984). To fit the data on desensitization, Katz \& Thesleff ( 1957 ) proposed that, in addition to the resting and open channel conformations, acetylcholine slowly and reversibly stabilizes a 'refractory' closed state with higher affinity for acetylcholine than the resting and active states. Parallel measurements on the same membranes of ion fluxes and agonist binding using the fluorescent agonist dansyl C6 choline (Heidmann \& Changeux, I 979, I 980) or radioactive acetylcholine (Boyd \& Cohen, 1980) offered a direct demonstration of the Katz \& Thesleff (r957) model (Heidmann et al. 1983 $b$; Neubig et al. 1982). Indeed, with Torpedo receptor the opening of the channel is associated with low-affinity binding $\left(K_{\mathrm{d}} 5 \circ \mu \mathrm{M}\right)$ and its desensitization with high-affinity states $\left(K_{\mathrm{d}}\right.$ I $\mu \mathrm{M}$ and г $\mathrm{nm}$ respectively, for the rapid and slowly desensitized states). In agreement with the two-state model of allosteric transition, a significant fraction of the sites $(20 \%)$ are under a highaffinity state even in the absence of agonists (Heidmann \& Changeux, r 979; Boyd $\&$ Cohen, 1980). The discrepancy between binding function and state function, a characteristic prediction of the two-state model, is thus verified. However, in contrast to classical allosteric proteins, the receptor undergoes multiple conformational transitions with strikingly different rates of interconversion between states that also possess different binding properties (see Grünhagen \& Changeux, 1976).

\section{(b) Evidence for conformational transitions of the receptor protein in the course of desensitization}

The structural changes which occur on transition from the resting to the desensitized 'equilibrium' state were probed at the level of the cholinergic ligand- 
binding site with DDF under rapid mixing conditions (Galzi et al. 199 I b). The allosteric effector meproadifen was used to stabilize the high-affinity desensitized state. Equilibration with meproadifen caused: (I) major increase in the rapid DDF labelling of the $\alpha$-subunit and (2) to a lesser extent, an enhanced incorporation of DDF in the $\delta$-subunit from the low-affinity d-tubocurarine site, and a decreased one in the $\gamma$-subunit from the high affinity d-tubocurarine site. These experiments thus reveal changes in the contribution of the $\alpha$-and non- $\alpha$-subunits to cholinergic ligand binding in the course of the desensitization transition. These observations are consistent with cryoelectron microscopy experiments showing that after equilibration of membrane-bound receptor with carbamylcholine, the quaternary structure rearrangements detected involve mainly the $\gamma$-and $\delta$-subunits (Unwin et al. I 988).

Also, in agreement with a tighter binding of cholinergic ligands to the desensitized receptor, differential labelling of the three peptide loops of the $\alpha$ subunit was detected: whereas residues $\alpha$-Tyri 90, $\alpha$-Cys I92-I93 (from loop C) were labelled in a roughly identical manner in resting and desensitized conformations, the labelling of amino acid $\alpha$-Tyr93 (from loop A) and $\alpha$-Trpi 49 (from loop B) increased up to six-fold relative to the resting state (Galzi et al. I 99 I $b$ ). Thus, the desensitization transition affects both the quaternary structure of the receptor oligomer and the tertiary folding of at least some of its subunits.

Site-directed mutagenesis of amino acids from the MII segment has brought rather unexpected aspects of desensitization relevant to the channel domain (Revah et al. I991; Bertrand et al. I992). In the previous chapter, it was mentioned that a highly conserved Leu ring was labelled by chlorpromazine (Giraudat et al. 1987; Revah et al. 1 990). To unravel its physiological significance, its homologue in the $\alpha 7$-homooligomeric receptor (Leu247) was mutated into a polar residue (e.g. a Thr). The L247'T permutation (Revah et al. I 99 I) abolished the inhibition of the channel blocker QX222, decreased the rate of desensitization of the response and increased the apparent affinity for acetylcholine. Such a pleiotropic effect of a point mutation might a priori be thought of as resulting from some kind of 'folding mutation' which would perturb the whole threedimensional architecture of the molecule. But the mutated molecule still possesses a functional channel and exhibits positive cooperativity as the wild-type receptor. A more plausible interpretation thus places emphasis on the mentioned allosteric properties of the acetylcholine receptor. For instance, equilibration with a nicotinic agonist results in the stabilisation of a desensitized state which exhibits high affinity for agonists and for some competitive antagonists (Grünhagen \& Changeux, 1976; Cohen \& Strnad, 1987). Now, if one assumes that this (or one of these) desensitized state has its channel open as a consequence of the mutation, then desensitization would become less effective. Instead, a stabilization of an open desensitized state would take place at low agonist concentration. Two additional observations further support this interpretation. First, single-channel recordings in the $\mathrm{L} 247 \mathrm{~T}$ mutant reveal a new conducting state of $80 \mathrm{pS}$ (in addition to the $46 \mathrm{pS}$ of the wild type) which is activated by low acetylcholine concentrations (Revah et al. I99 I, Fig. 7). Second, antagonists of the wild type 

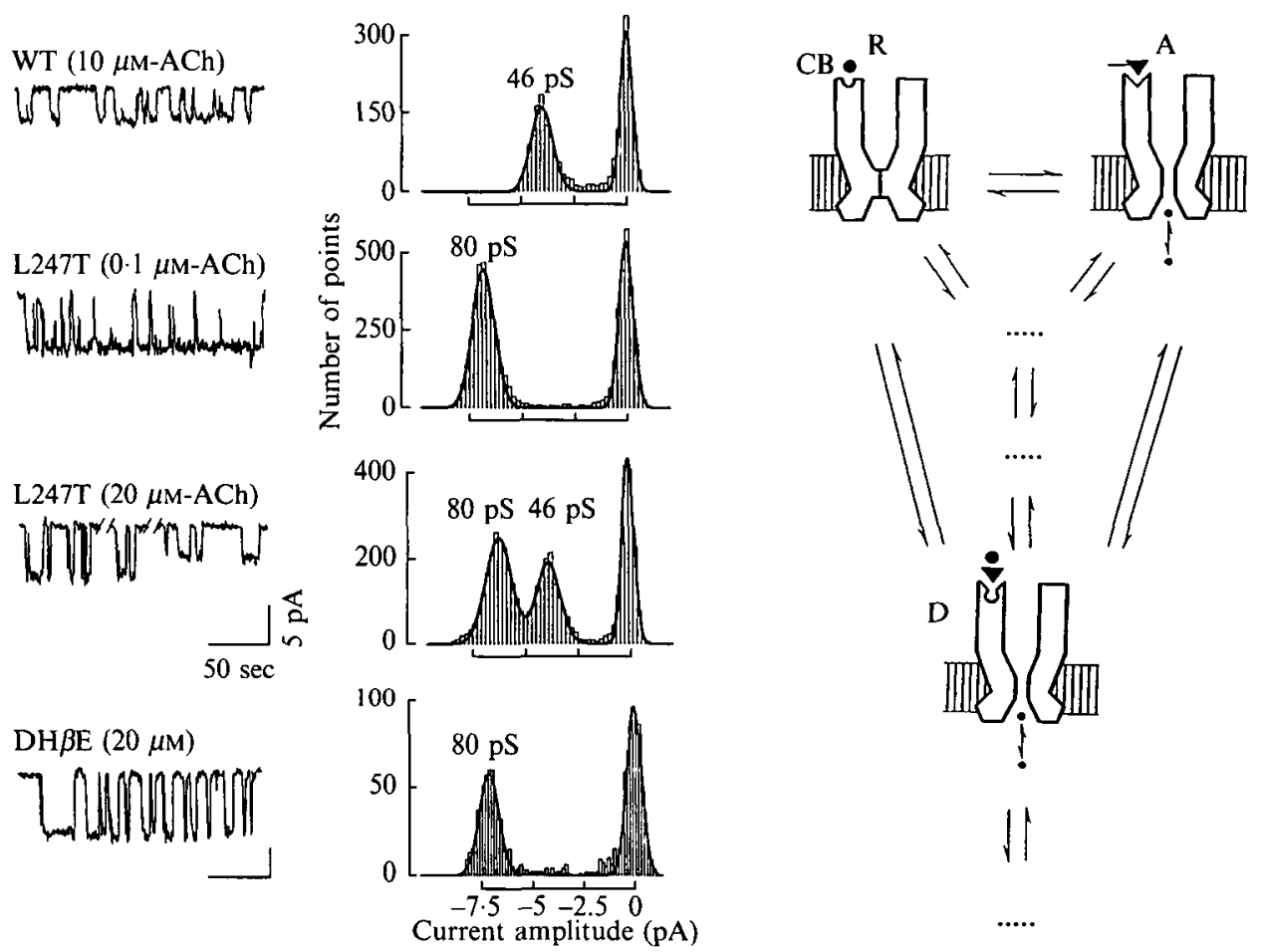

Current amplitude (pA)

Fig. 7. Role of the MII 'leucine ring' revealed by the single-channel recordings of $\alpha 7$ L247 T mutant expressed in frog oocyte. Low concentrations of acetylcholine $(<\mathrm{I} \mu \mathrm{M})$ activate a large conductance $(80 \mathrm{pS})$ absent in the wild type receptor. High concentrations of acetylcholine ( $>$ I $\circ \mu \mathrm{M}$ ) activate a $46 \mathrm{pS}$ conductance identical to that of the wild type receptor in addition to the large conductance. Dihydro- $\beta$-erythroidine $(\mathrm{DH} \beta \mathrm{E})$, a competitive antagonist of the WT receptor, activates the large conductance of the $\mathrm{L} 247 \mathrm{~T}$ mutant. Mean conductance values determined at $-100 \mathrm{mV}$ are indicated. The effects of the L247 $\mathrm{T}$ mutation are interpreted in the framework of a multiple state model, as rendering one of the desensitized states conducting (modified from Revah et al., I99 I and Bertrand et al. 1992).

receptor, such as dihydro- $\beta$-erythroidine, hexamethonium and d-tubocurarine behave as agonists when applied to the $\mathrm{L} 247 \mathrm{~T}$ mutant and activate this novel $80 \mathrm{pS}$ channel (Bertrand et al. 1992). The mutation thus renders accessible to electrophysiological techniques, states which are closed in the wild type. Conversely, in the wild type, this Leu ring would contribute to the closing of the ion channel in the desensitized conformation of the receptor. The model proposed for the Leu-zipper in other categories of regulatory proteins may, of course, be extended to this function.

A variety of effectors that appear to bind to allosteric sites distinct from the acetylcholine-binding sites and from the ion channel may differentially bind to each of these multiple states and thus indirectly regulate the permeability to acetylcholine. For example, $\mathrm{Ca}^{2+}$, electrical potential, reversible allosteric effectors such as some noncompetitive blockers binding to their low-affinity sites, 
and components of the lipid phase (such as cholesterol) regulate the rate of desensitization (see Changeux et al. 1984; Changeux, 1990; Ochoa et al. 1989, 1992). Also, the acetylcholine receptor is known to be phosphorylated in vitro ('Teichberg \& Changeux, 1976, I 977; Teichberg et al. 1977; Gordon et al. 1977; Vandlen et al. I 979). Three protein kinases exist in Torpedo electric organ and a variety of phosphorylation sites have been identified on the small hydrophilic segments assumed to face the cytoplasm in the standard four-helix model (Yee \& Huganir, 1987; Safran et al. 1987; Wagner et al. 1991; review Huganir \& Greengard, I990; Fig. 4). Phosphorylation accelerates desensitization in reconstituted receptor-rich membranes and in vitro (Huganir \& Greengard, I 990). Single-channel recordings with acetylcholine receptor reconstituted into lipid bilayers, however, reveal agonist-independent activation of receptor channels by protein kinase A phosphorylation (Ferrer-Montiel et al. I 99I).

Accelerated desensitization of the acetylcholine receptor (Mulle et al. I 988) has been observed in cultured muscle cells derived from mouse soleus muscle after treatment with calcitonin gene-related peptide (CGRP). This neuropeptide coexists with acetylcholine in spinal cord motor neurons (for review, see Villar et al. 1989) and can be released by nerve cells. It is plausible that the progressive enhancement of the rapid-decay phase of receptor desensitization by CGRP (Mulle et al. I 988) involves cyclic-AMP as a second messenger and cyclic-AMPdependent phosphorylation of the receptor (Miles et al. 1989). CGRP appears as an excellent candidate for a first messenger of neural origin to regulate postsynaptic receptor efficacy by enhancing its desensitization via phosphorylation. Covalent modifications may thus contribute to the regulation of the receptor response in addition, or as an alternative to the reversible binding of allosteric ligands to the receptor protein.

Several of the amino acid-gated ion channels, such as the $\mathrm{GABA}_{\mathrm{A}}$ and Gly receptors and the various species of glutamate receptor, display multiple conductance states, and direct transitions between some of these states have been reported to occur (Cull-Candy \& Usowicz, I989; Jahr and Stevens, I989). Moreover, in the case of the non-NMDA (AMPA) glutamate receptors the response to some of the agonists desensitizes (quisqualate or AMPA) whereas that to other agonists (kainate or domoate) does not (see Ascher \& Nowak, 1988; Patneau \& Mayer, I 991). Thus, it appears appropriate to extend to these receptors the scheme which accounts for the properties of the $\alpha_{7}-\mathrm{L}_{247} \mathrm{~T}$ mutant (Bertrand et al. 1992). The multiple-states model proposed for the acetylcholine receptor (Heidmann \& Changeux, I 982; Neubig et al. I 982) would then be expected to fit the properties of the other members of the superfamily of ligand-gated ion channels, provided that several (not only one) of these multiple states are conducting.

From an evolutionary point of view, the data obtained with the nicotinic receptor illustrate how simple genetic events affecting conformational schemes common to all these proteins and built upon shared principles of tertiary and quaternary structure may plausibly account for the diverse properties observed within the superfamily of ligand-gated ion channels. 


\section{CONCLUSIONS}

The nicotinic receptor from fish electric organ, muscle and brain, is a transmembrane regulatory protein, which possesses several basic properties in common with other neurotransmitter-gated ion channels. As a consequence, it has become the prototype of a wider superfamily of pharmacological receptors which includes, in addition to the glycine and $\mathrm{GABA}_{\mathrm{A}}$ receptor, the ${ }_{5} \mathrm{HT}_{3}$ receptor and the diverse species of glutamate receptors (see Galzi et al. I99 I $a$; Cockcroft et al. I 992). Common schemes for the three dimensional organization of the quaternary structure, of the common backbone of the subunits, of the detailed structure of the receptor sites and ion channel and of the conformational transitions in the course of activation and desensitization have been suggested. Canonical amino acids conserved throughout the whole superfamily would contribute to the common features of the functional architecture, while the variability of some amino acid side chains would account, as in immunoglobulins (Chothia et al. I 989), for the specificity of recognition of the neurotransmitter (and related pharmacological ligands) and for the ion transported (see Galzi et al. I99 I $a, b$ ).

From a pharmacological and biomedical point of view, these general principles of functional architecture support the notions that: (I) a single receptor molecule may be the target of several different series of pharmacological agents binding to topographically distinct sites, for instance 'allosteric' sites in addition to the neurotransmitter binding sites (e.g. glycine and glutamate on the NMDA receptor, benzodiazepines and GABA on the $\mathrm{GABA}_{\mathrm{A}}$ receptor); (2) some of these drug-binding sites might be located in the axial cleft of pseudo-symmetrical oligomers (such as for chlorpromazine, phencyclidine and various local anesthetics on the nicotinic receptor) and/or overlap the boundaries between subunits (for instance d-tubocurarine on the nicotinic receptor); (3) the interaction between pharmacological agents binding to these diverse categories of sites may not be 'steric' but may take place between topographically distinct sites, being mediated by conformational transitions of the receptor protein in a wide range of time-scales.

In agreement with a suggestion made more than 20 years ago (see Changeux, I 969), the nicotinic receptor thus shares several properties with classical allosteric proteins (Monod et al. I963, I965; Rubin \& Changeux, I966): ( I) an oligomeric quaternary structure; (2) the presence of several categories of topographically distinct sites linked by both homotropic and heterotropic interactions; (3) the allor-none opening and closing of the ion channel; (4) the conformational transitions between discrete states which differ by their ligand specificity (and affinity) and by the opening of the ion channel and which may spontaneously exist in the absence of ligand; (5) the distinction among pharmacological agents between agonists, which stabilize the open channel state and competitive antagonists, which preferentially stabilize the closed states [partial agonists might 'non exclusively' (Rubin \& Changeux, I966) bind to both states].

Moreover, these ligand-gated ion channels display features distinct from those of 'classical' globular allosteric proteins: (I) a unique axis of rotation for 
pentameric pseudo-symmetry; (2) the occurrence of homotropic interactions for pharmacological ligands which takes place between partially equivalent and pharmacologically distinct binding sites; (3) the access to multiple conformational transitions with time-scales varying from the microsecond to the minute (and even longer) time ranges (see Chang $\&$ Neumann, 1976). Several of these features may plausibly be associated with the transmembrane polarity of the protein molecule and its specialization in the transduction of chemical signals involved in intercellular communications. This conception of ligand-gated ion channels as allosteric proteins may be viewed as an attempt to bridge the gap between structural chemistry and physiology by placing emphasis on the quaternary organization and tertiary folding of the protein which would command the transport activity (or 'catalysis') of the ion channel. It is, of course, consonant with Peter Läuger's penetrating views on ion movements within channels ( 1987 ), in which he emphasized the importance of the flexibility and internal motion of channel proteins in the regulation of ion translocation through membranes.

\section{ACKNOWLEDGEMENTS}

This work was supported by grants from the Association Française contre les Myopathies, the College de France, the Centre National de la Recherche Scientifique, the Ministère de la Recherche, the Institut National de la Recherche Médicale, the Direction des Recherches Etudes et Techniques, and the Swiss National Science Foundation. We wish to thank Sonia Bertrand and Nicolas Hussy for their contribution to some parts of the work.

\section{REFERENCES}

Abramson, S. N., Li, Y., Culver, P. \& Taylor, P. (1989). An analog of lophotoxin reacts covalently with Tyr 190 in the $\alpha$-subunit of the nicotinic acetylcholine receptor. J. biol. Chem. 264, 1 2666-1 2672.

Adams, P. R. (I98I). Acetylcholine receptor kinetics. F. Membrane Biol. 58, i6 I-I 74. Albuquerque, E. X., Alkondon, M., Lima-landman, M. T., Deshpande, S. S. \& RAMOA, A. S. (1988). Molecular targets on noncompetitive blockers at the central and peripheral nicotinic and glutamatergic receptors. In Neuromuscular function, vol. I 3 (ed. L. S. Sellin, R. Libelius and S. Thesleff), pp. 273-300. New York: Elsevier.

Anand, R., Conroy, W. G., Schoepfer, R., Whiting, P. \& Lindstrom, J. (ig9i). Neuronal nicotinic acetylcholine receptors expressed in Xenopus oocytes have a pentameric quaternary structure. $\mathcal{F}$. biol. Chem. 266, I I192-1 I 198.

Aracava, Y., Deshpande, S. S., Swanson, K. L., Rapoport, H., Wonnacott, S., Lunt, G. \& Albuquerque, E. X. (1987). Nicotinic acetylcholine receptors in cultured neurons from the hippocampus and brain stem of the rat characterized by single channel recording. FEBS Lett. 222, 63-70.

Ascher, P. \& Nowak, L. ( 1988 ). Quisqualate and kainate activated channels in mouse central neurons in culture. F. Physiol. 399, 227-245.

Barkas, T., Mauron, A., Roth, B., Alliod, C., Tzartos, S. J. \& Ballivet, M. (i987). Mapping the main immunogenic region and toxin-binding site of the nicotinic acetylcholine receptor. Science $\mathbf{2 3 5}, \mathbf{7 7 - 8 0}$. 
Barnard, E. A., Darlison, M. G. \& Seeburg, P. (1987). Molecular biology of the $\mathrm{GABA}_{\mathrm{A}}$ receptor: the receptor/channel superfamily. Trends in Neurosci. 10, 502-509.

Becker, C. M., НосH, W. \& BeTz, H. (1988). Glycine receptor heterogeneity in rat spinal cord during postnatal development. EMBO $\mathcal{~ F . ~ 7 , ~ 3 7 1 ~ 7 - 3 7 2 6 . ~}$

Bertrand, D., Devillers-Thiéry, A., Revah, F., Galzi, J.-L., Hussy, N., Mulle, C., Bertrand, S., Ballivet, M. \& Changeux, J.-P. (i992). Unconventional pharmacology of a neuronal nicotinic-receptor mutated in the channel domain. Proc. natn. Acad. Sci. USA 89, 1261-1265.

Blount, P. \& Merlie, J. P. (1989). Molecular basis of the two nonequivalent ligand binding sites of the muscle nicotinic acetylcholine receptor. Neuron 3, 349-357.

Bon, F., Lebrun, E., Gomel, J., Van Rappenbusch, R., Cartaud, J., Popot, J. L. \& Changeux, J.-P. (I982). Orientation relative de deux oligomères constituant la forme lourde du récepteur de l'acétylcholine chez la Torpille marbrée. C. R. Acad. Sci. Paris 295, 199-203.

Bon, F., Lebrun, E., Gomel, J., Van Rappenbusch, R., Cartaud, J., Popot, J. L. \& Changeux, J.-P. (I984). Image analysis of the heavy form of the acetylcholine receptor from Torpedo marmorata. \%. molec. Biol. 176, 205-237.

Boulter, J., O'Shea-Greenfield, A., Duvoisin, R. M., Connolly, J. G., Wada, E., Jensen, A., Gardner, P. D., Ballivet, M., Deneris, E. S., McKinnon, D., Heinemann, S. \& Patrick, J. (I990). $\alpha_{3}, \alpha_{5}$, and $\beta_{4}$ : three members of the rat neuronal nicotinic acetylcholine receptor-related gene family form a gene cluster. $\mathcal{Y}$. biol. Chem. 265, 4472-4482.

Boyd, N. D. \& CoHEN, J. B. (1980). Kinetics of binding of $\left[{ }^{3} \mathrm{H}\right]$ acetylcholine and $\left[{ }^{3} \mathrm{H}\right]$ carbamoylcholine to Torpedo postsynaptic membranes: slow conformational transitions of the cholinergic receptor. Biochemistry 19, 5344-5358.

Brandl, C. J. \& Deber, C. M. (I986). Hypothesis about the function of membraneburied proline residues in transport proteins. Proc. natn. Acad. Sci. USA 83, 9 1 7-92 I.

Brisson, A. \& UNWIN, P. N. T. (1985). Quaternary structure of the acetylcholine receptor. Nature 315, 474-477.

Campbell, I. D. (1988). The structure and dynamics of membrane spanning helices by high resolution NMR and molecular dynamics. In Transport through Membranes: Carriers, Channels and Pumps (ed. A. Pullman et al.), pp. 91-10 I.

Chang, H. W. \& Neumann, E. (1976). Dynamic properties of isolated acetylcholine receptor proteins: release of calcium ions caused by acetylcholine binding. Proc. natn. Acad. Sci. USA 73, 3364-3368.

Changeux, J.-P. (196I). The feedback control mechanism of biosynthetic L-threonine deaminase by L-isoleucine. Cold Spring Harbor Symp. Quant. Biol. 26, 31 3-318.

ChangeuX, J.-P. ( ( 965). Sur les propriétés allostériques de la $L$-thréonine désaminase de biosynthèse. VI. Discussion générale. Bull. Soc. Chim. Biol. 47, 281-300.

Changeux, J.-P. ( I 966). Responses of acetylcholinesterase from Torpedo marmorata to salts and curarizing drugs. Mol. Pharmacol. 2, 369-392.

Changeux, J.-P. (1969). Remarks on the symmetry and cooperative properties of biological membranes. In Symmetry and Functions of Biological Systems at the Macromolecular Level (ed. A. Engström and B. Stranberg), Nobel Symposium No. I I. Wiley Interscience Division, New York, pp. 235-256.

Changeux, J.-P. (1980). Les expériences de Claude Bernard sur le curare et les données actuelles sur la transmission synaptique cholinergique. In La transmission neuromusculaire. Les médiateurs et le milieu intérieur. Fondation Singer Polignac (ed. Masson), pp. $7 \mathrm{I}-87$. 
Changeux, J.-P. ( $198 \mathrm{I}$ ). The acetylcholine receptor: an 'allosteric' membrane protein. In Harvey Lectures 75, 85-254. Academic Press.

Changeux J.-P. (1990). Functional architecture and dynamics of the nicotinic acetylcholine receptor: an allosteric ligand-gated ion channel. Fidia Research Foundation Neuroscience Award Lectures, vol. 4 (ed. J.-P. Changeux, R. R. Llinas, D. Purves and F. E. Bloom), pp. $21-168$. Raven Press Ltd.

Changeux, J.-P., Thiéry, J. P., Tung, Y. \& Kittel, C. (1967a). On the cooperativity of biological membranes. Proc. natn. Acad. Sci. USA 57, 335-34I.

Changeux, J.-P., Podleski, T. \& Wofsy, L. (1967b). Affinity labeling of the acetylcholine receptor. Proc. natn. Acad. Sci. USA 58, 2063-2070.

Changeux, J.-P., Kasai, M. \& Lee, C. Y. (I970a). The use of a snake venom toxin to characterize the cholinergic receptor protein. Proc. natn. Acad. Sci. USA 67, $1241-1247$.

Changeux, J.-P., Kasai, M., Huchet, M. \& Meunier, J. C. ( 1970 b). Extraction à partir du tissu électrique de gymnote d'une protéine présentant plusieurs propriétés caractéristiques du récepteur physiologique de l'acétylcholine. C. R. Acad. Sci. 27o D, 2864-2867.

Changeux, J.-P., Devillers-Thiéry, A. \& Chemouilli, P. (i 984). Acetylcholine receptor: an allosteric protein. Science 225, I335-1 345 .

Changeux, J.-P., Pinset, C. \& Ribera, A. B. (i 986). Effects of chlorpromazine and phencyclidine on mouse $\mathrm{C}_{2}$ acetylcholine receptor kinetics. $\mathcal{F}$. physiol. 378, 497-5 I 3 .

Charnet, P., Labarca, C., Leonard, R. J., Vogelaar, N. J., Czyzyk, L., Gouin, A., Davidson, N. \& Lester, H. A. (I990). An open-channel blocker interacts with adjacent turns of $\alpha$-helices in the nicotinic acetylcholine receptor. Neuron 2, 87-95.

Chothia, C. \& Lesk, A. M. (1985). Helix movements in proteins. Trends in Biochem. Sci. 10, I I6-I I8.

Chothia, C., Lesk, A. M., Tramontano, A., Levitt, M., Smith-Gill, S. J., Air, G., Sheriff, S., Padlan, E. A., Davis, D., Tulip, W. R., Colman, P. M., Spinelli, S., Alzari, P. M. \& Poljak, R. J. (1989). Conformations of immunoglobulin hypervariable regions. Nature $\mathbf{3 4 2}, 877-88_{3}$.

Claudio, T., Ballivet, M., Patrick, J. \& Heinemann, S. (1983). Nucleotide and deduced amino acid sequences of Torpedo californica acetylcholine receptor gammasubunit. Proc. natn. Acad. Sci. USA 80, I I I I-I I I 5.

Cockcroft, V. B., Osguthorpe, D. J., Barnard, E. A. \& Lunt, G. G. (1 990). Modeling of agonist binding to the ligand-gated ion channel superfamily of receptors. Proteins : Structure, Function and Genetics 8, 386-397.

Cockcroft, V. B., Osguthorpe, D. J., Barnard, E. A., Friday, A. E. \& Lunt, G. G. (1992). Ligand-gated ion channels: homology and diversity. Mol. Neurobiol. 4, I 29-I 69 .

Cohen, J. \& Strnad, N. (1987). Permeability control and desensitization by nicotinic acetylcholine receptors. In Molecular Mechanisms of Desensitization to Signal Molecules, vol. H6 (ed. T. M. Konijn), pp. 257-273. Nato ASI series, Berlin: Springer.

Cohen, J. B., Weber, M. \& Changeux, J.-P. (1974). Effects of local anesthetics and calcium on the interaction of cholinergic ligands with the nicotinic receptor protein from Torpedo marmorata. Mol. Pharmacol. 10, 904-932.

Cohen, J. B., Sharp, S. D. \& Liu, W. S. (I99I). Structure of the agonist-binding site of the nicotinic acetylcholine receptor. $\mathcal{F}$. biol. Chem. 266, 23354-23364. 
Cohen, J. B., Blanton, M. P., Chiara, D. C., Sharp, S. D. \& White, B. H. (I992). Structural organization of functional domains of the nicotinic acetylcholine receptor. 7. Cell. Biochem. : Keystone Symposia, T 003 , p. 2 i 7.

Colquhoun, D. (1979). The link between drug binding and response: theories and observations. In The Receptors: General Principles and Procedures, vol. I (ed. R. D. O'Brien), pp. 93-142. Plenum Press.

Colquhoun, D. \& Sakmann, B. (1985). Fast-events in single-channel currents activated by acetylcholine and its analogues at the frog muscle endplate. $\mathscr{F}$. Physiol. 369, $501-557$.

Conti-Tronconi, B. M., Tang, F., Walgrave, S. \& Gallagher, W. (i990). Nonequivalence of $\alpha$-bungarotoxin binding sites in the native nicotinic receptor molecule. Biochemistry 29, 1046-1054.

Cooper, E., Couturier, S. \& Ballivet, M. (I99i). Pentameric structure and subunit stoichiometry of a neuronal nicotinic acetylcholine receptor. Nature $350,235^{-2} 38$.

Couturier, S., Bertrand, D., Matter, J. M., Hernandez, M. C., Bertrand, S., Millar, N., Valera, S., Barkas, T. \& Ballivet, M. (I990a). A neuronal nicotinic acetylcholine receptor subunit $\left(\alpha_{7}\right)$ is developmentally regulated and forms a homooligomeric channel blocked by $\alpha$-BTX. Neuron $5,845-856$.

Couturier, S., Erkman, L., Valera, S., Rungger, D., Bertrand, S., Boulter, J., Ballivet, M. \& Bertrand, D. (1990 $b$ ). $\alpha_{5}, \alpha_{3}$ and non- $\alpha_{3}$ : three clustered avian genes encoding neuronal nicotinic acetylcholine receptor related subunits. $\mathcal{F}$. biol. Chem. 265, $17560-17567$.

Cox, R. N., Kaldany, R. R., DiPaola, M. \& Karlin, A. (1985). Time-resolved photolabeling by quinacrine azide of a non-competitive inhibitor site of the nicotinic acetylcholine receptor in a transient agonist-induced state. $\mathcal{F}$. biol. Chem. 260, 7 I 86-7 193 .

Cull-Candy, S. C. \& Usowicz, M. M. (i989). On the multiple-conductance single channels activated by excitatory amino acids in large cerebellar neurones of the rat. $\mathcal{F}$. Physiol. 415, 555-582.

Culver, P., Fenical, W. \& Taylor, P. (1984). Lophotoxin irreversibly inactivates the nicotinic acetylcholine receptor by preferential association at one of the two primary agonist sites. F. biol. Chem. 259, 3763-3770.

Czajkowski, C. \& Karlin, A. (I99I). Agonist binding site of Torpedo electric tissue nicotinic acetylcholine receptor: a negatively charged region of the gamma subunit within $0.9 \mathrm{~nm}$ of the $\alpha$ subunit binding site disulfide. F. biol. Chem. 266, 22603-226 2.

Dale, H. H. ( I 9 I 4). The actions of certain esters and esters of choline, and their relation to muscarine. F. Pharmacol. exp. Ther. 6, I47-I90.

Damle, V. N., Mclaughlin, M. \& Karlin, A. (1978). Bromoacetylcholine as an affinity label of the acetylcholine receptor from Torpedo californica. Biochem. biophys. Res. Comm. 84, 845-851.

Delegeane, A. M. \& MCNamee, M. G. (1980). Independent activation of the acetylcholine receptor from Torpedo californica at two sites. Biochemistry 19, 890-895.

Dennis, M., Giraudat, J., Kotzyba-Hibert, F., Goeldner, M., Hirth, C., Chang, J. Y. \& Changeux, J.-P. (1986). A photoaffinity ligand of the acetylcholine binding site predominantly labels the region $179-207$ of the $\alpha$-subunit on native acetylcholine receptor from Torpedo marmorata. FEBS Lett. 207, 243-249.

Dennis, M., Giraudat, J., Kotzyba-Hibert, F., Goeldner, M., Hirth, C., Chang, J. Y., Lazure, C., Chrétien, M. \& Changeux, J.-P. (ig88). Amino acids of the 
Torpedo marmorata acetylcholine receptor $\alpha$ subunit labeled by a photoaffinity ligand for the acetylcholine binding site. Biochemistry 27, 2346-2357.

Devillers-Thiéry, A., Changeux, J.-P., Paroutaud, P. \& Strosberg, A. D. (1979). The amino-terminal sequence of the 40000 molecular weight subunit of the acetylcholine receptor protein from Torpedo marmorata. FEBS Lett. 104, 99-105.

Devillers-Thiéry, A., Giraudat, J., Bentaboulet, M. \& Changeux, J.-P. (i983). Complete mRNA coding sequence of the acetylcholine binding alpha subunit of Torpedo marmorata acetylcholine receptor: a model for the transmembrane organization of the polypeptide chain. Proc. natn. Acad. Sci. USA 80, 2067-2071.

Dhaenens, M., Lacombe, L., Lehn, J. M. \& Vigneron, J. P. (1984). Binding of acetylcholine and other molecular cations by a macrocyclic receptor molecule of speleand type. F. Chem. Soc. chem. Commun. 16, 1097-1099.

DiPaola, M., Czajkowski, C. \& Karlin, A. (1989). The sidedness of the COOH terminus of the acetylcholine receptor $\delta$-subunit. $\mathcal{F}$. biol. Chem. 264, I-7.

Dowding, A. J. \& HaLl, Z. W. (1987). Monoclonal antibodies specific for each of the two toxin-binding sites of Torpedo acetylcholine receptor. Biochemistry 26, 6372-638 r .

Duvoisin, R. M., Deneris, E. S., Patrick, J. \& Heinemann, S. (I989). The functional diversity of the neuronal nicotinic acetylcholine receptors is increased by a novel subunit: $\beta 4$. Neuron 3, 487-496.

Eisemann, G. \& Alvarez, O. (I99I). Structure and function of channels and channelogs as studied by computational chemistry. $\mathcal{F}$. Membrane Biol. I19, Io9-132.

Fahr, A., Lauffer, L., Schmidt, D., Heyn, M. P. \& Hucho, F. (1985). Covalent labelling of functional states of the acetylcholine receptor: effects of antagonists on the receptor conformation. Eur. F. Biochem. r47, 483-487.

Fenton, J. W. \& Singer, S. J. (I 965 ). Affinity labeling of antibodies to the $p$-azophenyltrymethylammonium hapten and a structural relationship among antibody active sites of different specificities. Biochem. biophys. Res. Commun. 20, 3 I 5-320.

Ferrer-Montiel, A. V., Montal, M. S., Diaz-Munoz, M. \& Montal, M. (ig9r). Agonist-independent activation of acetylcholine receptor channels by protein kinase $\mathrm{A}$ phosphorylation. Proc. natn. Acad. Sci. USA 88, 10213-102 I7.

Furois-Corbin, S. \& Pullman, A. (r988). Theoretical study of potential ion-channels formed by bundles of $\alpha$-helices. Partial modelling of the acetylcholine receptor channel. In Transport through Membranes: Carriers, Channels and Pumps (ed. A. Pullman et al.), pp. 337-357. Kluwer Academic Publishers.

Galzi, J.-L., Revah, F., Black, D., Goeldner, M., Hirth, C. \& Changeux, J.-P. (1990). Identification of a novel amino acid $\alpha$-Tyr93 within the active site of the acetylcholine receptor by photoaffinity labeling: additional evidence for a three-loop model of the acetylcholine binding site. $\mathcal{F}$. biol. Chem. 265, r0430-10437.

Galzi, J.-L., Revah, F., Bessis, A. \& Changeux, J.-P. ( I 99 I $a$ ). Functional architecture of the nicotinic acetylcholine receptor: from the electric organ to brain. Ann. Rev. Pharmacol. Toxicol. 3I, 37-72.

Galzi, J.-L., Revah, F., Bouet, F., Menez, A., Goeldner, M., Hirth, C. \& Changeux, J.-P. (I 99 I $b$ ). Allosteric transitions of the acetylcholine receptor probed at the amino acid level with a photolabile cholinergic ligand. Proc. natn. Acad. Sci. USA 88, 505 I-5055.

Galzi, J.-L., Bertrand, D., Devillers-Thiéry, A., Revah, F., Bertrand, S. \& Changeux, J.-P. ( 199 I $c$ ). Functional significance of aromatic amino acids from three peptide loops of the $\alpha 7$ neuronal nicotinic receptor site investigated by site-directed mutagenesis. FEBS Lett. 294, $198-202$. 
Gerhart, J. C. \& Pardee, A. B. (I962). The enzymology of control by feedback inhibition. F. biol. Chem. 237, $89 \mathrm{I}-896$.

Gershoni, J. M. (1987). Expression of the $\alpha$-bungarotoxin binding site of the nicotinic acetylcholine receptor by Escherichia coli transformants. Proc. natn. Acad. Sci. USA 84, 43 I 8-432 I.

Giraudat, J., Dennis, M., Heidmann, T., Chang, J. Y. \& Changeux, J.-P. (ig86). Structure of the high affinity binding site for noncompetitive blockers of the acetylcholine receptor: Serine-262 of the $\delta$ subunit is labeled by $\left[{ }^{3} \mathrm{H}\right]$ chlorpromazine. Proc. natn. Acad. Sci. USA 83, 2719-2723.

Giraudat, J., Dennis, M., Heidmann, T., Haumont, P. Y., Lederer, F. \& Changeux, J.-P. ( 1987 ). Structure of the high-affinity binding site for noncompetitive blockers of the acetylcholine receptor: $\left[{ }^{3} \mathrm{H}\right]$ chlorpromazine labels homologous residues in the beta and delta chains. Biochemistry 26, $2410-2418$.

Giraudat, J., Galzi, J. L., Revah, F., Changeux, J. P., Haumont, P. Y. \& Lederer, F. (1989). The noncompetitive blocker chlorpromazine labels segment MII but not segment $\mathrm{MI}$ on the nicotine acetylcholine receptor $\alpha$ subunit. FEBS Lett. 253 , 190-198.

Goeldner, M. P. \& Hirth, C. G. (i980). Specific photoaffinity labeling induced by energy transfer: application to irreversible inhibition of acetylcholinesterase. Proc. natn. Acad. Sci. USA 77, 6439-6442.

Goeldner, M. P., Hirth, C. G., Kieffer, B. \& Ourisson, G. (1982). Photosuicide inhibition - a step towards specific photoaffinity labelling. Trends biochem. Sci. 7 , 310-312.

Gordon, A., Davis, G. \& Diamond, I. (1977). Phosphorylation of membrane proteins at a cholinergic synapse. Proc. natn. Acad. Sci. USA 74, 263-267.

Gross, A., Ballivet, M., Rungger, D. \& Bertrand, D. (ig9i). Neuronal nicotinic acetylcholine receptors expressed in Xenopus oocytes: role of the alpha subunit in agonist sensitivity and desensitization. Pflügers Arch. 419, 545-55I.

Grünhagen, H. H. \& Changeux, J.-P. (1976). Studies on the electrogenic action of acetylcholine with Torpedo marmorata electric organ. Quinacrine: a fluorescent probe for the conformational transitions of the cholinergic receptor protein in its membrane bound state. $\mathcal{F}$. molec. Biol. 106, 497-516.

Gu, Y., Silberstein, L. \& Hall, Z. W. (1985). The effects of a myasthenic serum on the acetylcholine receptors of $\mathrm{C}_{2}$ myotubes. I. Immunological distinction between the two toxin-binding sites of the receptor. $\mathscr{F}$. Neurosci. 5, 1909-19I6.

Hazelbauer, G. \& Changeux, J. P. (i 974). Reconstitution of a chemically excitable membrane. Proc. Natn. Acad. Sci. U.S.A. 71, 1479-1483.

Heginbotham, L. \& McKinnon, R. (1992). The aromatic binding site for tetraethylammonium ion on potassium channels. Neuron 8, 483-49I.

Heidmann, T. \& Changeux, J.-P. (i 979). Fast kinetic studies on the interaction of a fluorescent agonist with the membrane-bound acetylcholine receptor from Torpedo marmorata. Eur. F. Biochem. 94, 281-296.

Heidmann, T. \& Changeux, J.-P. (I 980). Interaction of a fluorescent agonist with the membrane-bound acetylcholine receptor from Torpedo marmorata in the millisecond time range: resolution of an 'intermediate' conformational transition and evidence for positive cooperative effects. Biochem. biophys. Res. Comm. 97, 889-896.

Heidmann, T. \& Changeux, J.-P. (I982). Un modèle moléculaire de régulation d'efficacité d'une synapse chimique au niveau postsynaptique. C. R. Acad. Sci. Paris, série $3,295,665-670$. 
Heidmann, T., Oswald, R. E. \& Changeux, J. P. (r983a). Multiple sites of action for non competitive blockers on acetylcholine receptor rich membrane fragments from Torpedo marmorata. Biochemistry 22, 3 I I 2-3 127.

Heidmann, T., Bernhardt, J., Neumann, E. \& Changeux, J.-P. (1983b). Rapid kinetics of agonist binding and permeability response analysed in parallel on acetylcholine receptor rich membranes from Torpedo marmorata. Biochemistry 22, $545^{2-5459 .}$

Heidmann, T. \& Changeux, J.-P. (1984). Time-resolved photolabelling by the noncompetitive blocker chlorpromazine of the acetylcholine receptor in its transiently open and closed ion channel conformations. Proc. natn. Acad. Sci. USA 81, I 897-190 I.

Heidmann, T. \& Changeux, J.-P. (1986). Characterization of the transient agonisttriggered state of the acetylcholine receptor rapidly labeled by the noncompetitive blocker $\left[{ }^{3} \mathrm{H}\right]$ chlorpromazine: additional evidence for the open channel conformation. Biochemistry 25, 6 109-6 I I 3 .

Heinemann, S., Boulter, J., Deneris, E., Connolly, J., Gardner, P., Wada, E., Wada, K., Duvoisin, R., Ballivet, M., Swanson, L. \& Patrick, J. (i 989). Brain and muscle nicotinic acetylcholine receptor: a gene family. In Molecular Biology of Neuroreceptors and Ion Channels, vol. $\mathrm{H}_{32}$ (ed. A. Maelicke), pp. I3-30. Berlin, Heidelberg: Springer-Verlag.

Herz, J. M., Johnson, D. A. \& Taylor, P. (1989). Distance between the agonist and noncompetitive inhibitor sites on the nicotinic acetylcholine receptor. $\mathcal{F}$. biol. Chem. 264, I $2439-12448$.

Hess, G. P., Pasquale, E. B., Walker, J. W. \& McNamee, M. G. (i 982 ). Comparison of acetylcholine receptor-controlled cation flux in membrane vesicles form Torpedo californica and Electrophorus electricus: chemical kinetic measurements in the millisecond region. Proc. natn. Acad. Sci. USA 79, 963-967.

Hibert, M. F. \& Trumpp-Kallmeyer, S. T. (1991). Three-dimensional models of neurotransmitter G-protein coupled receptors. Mol. Pharmacol. 40, 8-I 5.

Hucho, F. L., Oberthür, W. \& Lottspeich, F. ( 1986). The ion channel of the nicotinic acetylcholine receptor is formed by the homologous helices MII of the receptor subunits. FEBS Lett. 205, I 37-1 42.

Huganir, R. L. \& Greengard, P. (1990). Regulation of neurotransmitter receptor desensibilization by protein phosphorylation. Neuron $5,555-567$.

Imoto, K., Methfessel, C., Sakmann, B., Mishina, M., Mori, Y., Konno, T., Fukuda, K., Kurasaki, M., Bujo, H., Fujita, Y. \& Numa, S. (i986). Location of a delta-subunit region determining ion transport through the acetylcholine receptor channel. Nature 324, 670-674.

Imoto, K., Busch, C., Sakmann, B., Mishina, M., Konno, T., Nakai, J., Bujo, H., Mori, Y., Fukuda, K. \& Numa, S. (1988). Rings of negatively charged amino acids determine the acetylcholine receptor channel conductance. Nature 335, 645-648.

Imoto, K., Konno, T., Nakai, J., Wang, F., Mishina, M. \& Numa, S. (i99i). A ring of uncharged polar amino acids as a component of channel constriction in the nicotinic acetylcholine receptor. FEBS Lett. 289, I 93-200.

JaCkson, M. B. (1984). Spontaneous openings of the acetylcholine receptor channel. Proc. natn. Acad. Sci. USA 81, 3901-3904.

JACKson, M. B. (1988). Dependence of acetylcholine receptor channel kinetics on agonist concentration in cultured mouse muscle fibres. $\mathcal{F}$. Physiol. 397, 555-583. 
JaCkson, M. B. (1989). Perfection of a synaptic receptor: kinetics and energetics of the acetylcholine receptor. Proc. natn. Acad. Sci. USA 86, 2 199-2203.

Jahr, C. E. \& Stevens, C. F. (r989). Glutamate activates multiple single channel conductances in hippocampal neurons. Nature 325, 522-525.

KaO, P. N. \& Karlin, A. (1986). Acetylcholine receptor binding site contains a disulfide cross-link between adjacent half-cystinyl residues. F. biol. Chem. 26r, 8085-8088.

Kao, P. N., Dwork, A. J., Kaldany, R. R. J., Silver, M. L., Wideman, J., Stein, S. \& Karlin, A. (1984). Identification of the alpha-subunit half-cystine specifically labeled by an affinity reagent for the acetylcholine receptor binding site. $\mathcal{F}$. biol. Chem. 259, I I 662-I I 665 .

KARLIN, A. (1980). Molecular properties of nicotinic acetylcholine receptors. In Cell Surface Reviews, vol. 6 (ed. G. Poste, G. L. Nicolson and C. W. Cotman), pp. I 9 I-260. New York.

Karlin, A. ( I 983 ). Anatomy of a receptor. Neuroscience Comment. I, I I I-I 23.

Karlin, A. (1991). Explorations of the nicotinic acetylcholine receptor. The Harvey Lectures Series 85, 71-107.

Karlin, A. \& WinNick, M. (ig68). Reduction and specific alkylation of the receptor for acetylcholine. Proc. natn. Acad. Sci. USA 6o, 668-674.

Kasai, M., Podleski, T. R. \& Changeux, J. P. (I970). Some structural properties of excitable membranes labelled by fluorescent probes. FEBS Lett. 7, 1 3-1 9.

Kasai, M. \& Changeux, J.P. (I97I). In vitro excitation of purified membrane fragments by cholinergic agonists. I. Pharmacological properties of the excitable membrane fragments. II. The permeability change caused by cholinergic agonists. III. Comparison of the dose response curves to decamethonium with the corresponding binding curves of decamethonium to the cholinergic receptor. F. Memb. Biology 6, I-80.

Katz, B. (1966). Nerve Muscle and Synapse. New York: McGraw and Hill Book Co.

Katz, B. \& Miledi, R. ( 1970 ). Membrane noise produced by acetylcholine. Nature 226, $962-963$.

Katz, B. \& Miledi, R. (I973a). The effect of atropine on acetylcholine action at the neuromuscular junction. Proc. R. Soc. B 184, $221-226$.

Katz, B. \& Mrledi, R. (1973 $b$ ). The characteristics of 'end-plate noise' produced by different depolarizing drugs. F. Physiol. 230, 707-7 I 7 .

Katz, B. \& Miledi, R. (I977). Transmitter leakage from motor nerve endings. Proc. R. Soc. B I96, 59-72.

KatZ, B. \& TheslefF, S. (I957). A study of the 'desensitization' produced by acetylcholine at the motor end-plate. F. Physiol. 138, 63-80.

Klarsfeld, A., Devillers-Thiéry, A., Giraudat, J. \& Changeux, J.-P. (ig84). A single gene codes for the nicotinic acetylcholine receptor alpha-subunit in Torpedo marmorata: structural and developmental implications. EMBO $\mathcal{F} .3,35-4 \mathrm{I}$.

Konno, T., Busch, C., Von Kitzing, E., Imoto, K., Wang, F., Nakai, J., Mishina, M., Numa, S. \& SakmanN, B. (I99I). Rings of anionic amino acids as structural determinants of ion selectivity in the acetylcholine receptor channel. Proc. $R$. Soc. B 244, 69-79.

Kuffler, S. W. \& Yoshikami, D. (I975). The distribution of acetylcholine sensitivity at the post-synaptic membrane of vertebrate skeletal twitch muscles: iontophoretic mapping in the micron range. $\mathcal{Y}$. Physiol. 244, 703-730.

Kunse, J., Schmieden, V. \& Betz, H. (1990). A single amino acid exchange alters the pharmacology of neonatal rat glycine receptor subunit. Neuron $\mathbf{5}, 867-873$. 
Kurosaki, 'T., Funuda, K., Konno, 'T., Mori, Y., Tanaka, K. I., Mishina, M. \& Numa, S. ( I 987). Functional properties of nicotinic acetylcholine receptor subunits expressed in various combinations. FEBS Lett. 214, 253-258.

Langenbuch-Cachat, J., Bon, C., Goeldner, M., Hirth, C. \& Changeux, J.-P. (1988). Photoaffinity labeling by aryldiazonium derivatives of Torpedo marmorata acetylcholine receptor. Biochemistry 27, 2337-2345.

LÄUger, P. (1987). Dynamics of ion transport systems in membranes. Physiol. Rev. 67, I 296-I 33 I.

LeE, C. Y. \& Chang, C. C. (rg66). Modes of actions of purified toxins from elapid venoms on neuromuscular transmission. Mem. Inst. Butantan Sao Paulo 33, 555-572.

Leonard, R. J., Labarca, C. G., Charnet, P., Davidson, N., Lester, H. A. (i 988 ). Evidence that the $M_{2}$ membrane-spanning region lines the ion channel pore of the nicotinic receptor. Science 242, I 578-1 58 I.

Lipton, S. A., Aizenman, E. \& Loring, R. H. (i987). Neural nicotinic acetylcholine responses in solitary mammalian retinal ganglion cells. Pflügers Arch. 410, 37-43.

Loring, R. H., Chiapinelli, V. A., Zigmond, R. E. \& Cohen, J. B. (i984). Characterization of a snake venom neurotoxin which blocks nicotinic transmission in the avian ciliary ganglion. Neuroscience 11, 989-999.

Luetje, C. W., Wada, K., Rogers, S., Abramson, S. N., Tsuji, K., Heinemann, S. \& Patrick, J. (I990). Neurotoxins distinguish between different neuronal nicotinic acetylcholine receptor subunit combinations. $\mathscr{F}$. Neurochem. 55, 632-640.

Luyten, W. H. M. L. (1986). A model for the acetylcholine binding site of the nicotinic acetylcholine receptor. $\mathcal{F}$. Neurosci. Res. I6, $5 \mathrm{I}-73$.

McCrea, P. D., Popot, J. L. \& Engelman, D. M. (1987). Transmembrane topography of the nicotinic acetylcholine receptor delta-subunit. $E M B O \mathcal{F} .6,3619-3626$.

McNamee, M. G. \& OCHOA, E. L. M. (1982). Reconstitution of acetylcholine receptor function in model membranes. Neuroscience 7, 2305-23I 9.

MaElicke, A. \& Reich, E. (r976). On the interaction between Cobra alpha-neurotoxin and the acetylcholine receptor. Cold Spring Harb. Symp. Quant. Biol. 40, 203-2 10.

Maelicke, A., Fulpius, B. W., KLett, R. P. \& Reich, E. ( I 977). Acetylcholine receptor responses to drug binding. F. biol. Chem. 252, 48 I I-4830.

MaricQ, A. V., Peterson, A. S., Brake, A. J., Myers, R. M. \& Julius, D. (I991). Primary structure and functional expression of the $5 \mathrm{HT}_{3}$ receptor, a serotonin-gated ion channel. Science 254, 432-437.

Merlie, J. P., Sebbane, R., Gardner, S. \& Lindstrom, J. (i983). cDNA clone for the alpha-subunit of the acetylcholine receptor from the mouse muscle cell line $\mathrm{BC}_{3} \mathrm{H}-\mathrm{I}$. Proc. natn. Acad. Sci. USA 8o, 3845-3849.

Middleton, R. E. \& Cohen, J. B. (I99I). Mapping of the acetylcholine binding site of the nicotinic acetylcholine receptor: $\left[{ }^{3} \mathrm{H}\right]$ nicotine as an agonist photoaffinity label. Biochemistry 30, 6987-6997.

Miles, K., Greengard, P. \& Huganir, R. L. (ig89). Calcitonin gene-related peptide regulates phosphorylation of the nicotinic acetylcholine receptor in rat myotubes. Neuron 2, I 5 I 7-1 524 .

Mishina, M., Tobimatsu, T., Imoto, K., Tanaka, K., Fujita, Y., Fukuda, K., Kurasaki, M., Takahashi, H., Morimoto, Y., Hirose, T., Inayama, S., Takahashi, T., Kuno, M. \& Numa, S. (1985). Location of functional regions of acetylcholine receptor alpha-subunit by site-directed mutagenesis. Nature 313, 364-369.

Monod, J., Changeux, J.-P. \& Jacob, F. (1963). Allosteric proteins and cellular control systems. F. molec. Biol. 6, 306-329. 
Monod, J., Wyman, J. \& Changeux, J.-P. (I965). On the nature of allosteric transitions: a plausible model. $\mathcal{F}$. molec. Biol. 12, 88-1 I 8.

Montal, M., Anholt, R. \& Labarca, P. (1986). The reconstituted receptor. In Ion Channel Reconstitution (ed. C. Miller), pp. I 57-204. Plenum.

Mosckovitz, R. \& Gershoni, J. M. (i 988). Three possible disulfides in the acetylcholine receptor $\alpha$-subunit. $\mathcal{F}$. biol. Chem. 263, 1017-1022.

Muhn, P., FAHr, A. \& Hucho, F. (I984). Photoaffinity labeling of acetylcholine receptor in millisecond time scale. FEBS Lett. I, $146-150$.

Mulac-Jericevic, B. \& Atassi, M.Z. (I986). Segment alpha-182-I98 of Torpedo californica acetylcholine receptor contains a second toxin-binding region and binds anti-receptor antibodies. FEBS Lett. 199, 68-74.

Mulle, C. \& Changeux, J.-P. (I 990). A novel type of nicotinic receptor in the rat central nervous system characterized by patch-clamp techniques. $\mathscr{Y}$. Neurosci. ro, I69-1 75.

Mulle, C., Benoit, P., Pinset, C., Roa, M. \& Changeux, J.-P. ( i 988). Calcitonin generelated peptide enhances the rate of desensitization of the nicotinic acetylcholine receptor in cultured mouse muscle cells. Proc. natn. Acad. Sci. USA 85, 5728-5732.

Mulle, C., Vidal, C., Benoit, P. \& Changeux, J. P. (1991). Existence of different subtypes of nicotinic acetylcholine receptor in the rat habenulo interpeduncular system. F. Neurosci. II, 2588-2597.

Mulle, C., Choquet, D., Korn, H. \& Changeux, J. P. (I992). Calcium influx through nicotinic receptor in rat central neurons; its relevance to cellular regulations. Neuron 8, $135^{-1} 43$.

Nachmansohn, D. (1959). Chemical and Molecular Basis of Nerve Activity, pp. 235. New York: Academic Press.

Neher, E. \& Sakmann, B. (1976a). Noise analysis of drug-induced conductance voltage clamp currents in denervated frog muscle fibres. $\mathcal{F}$. Physiol. 258, 705-729.

Neher, E. \& SakmanN, B. (1976b). Single channel currents recorded from membrane of denervated frog muscle fibres. Nature 260, 799-802.

Neher, E. \& Steinbach, J. H. (1978). Local anaesthetics transiently block currents through single acetylcholine-receptor channels. $\mathcal{F}$. Physiol. 277, 153-176.

Neubig, R. R. \& CoHen, J. B. (1979). Equilibrium binding of $\left[{ }^{2} \mathrm{H}\right]$ tubocurarine and $\left[{ }^{3} \mathrm{H}\right]$ acetylcholine by Torpedo postsynaptic membranes: stoichiometry and ligand interactions. Biochemistry 18, 5464-5475.

Neubig, R. R. \& Cohen, J. B. (I980). Permeability control by cholinergic receptors in Torpedo post synaptic membranes: agonist dose response relations measured at second and millisecond times. Biochemistry 19, 2770-2779.

Neubig, R. R., Boyd, N. D. \& Cohen, J. B. (1982). Conformations of Torpedo acetylcholine receptor associated with ion transport and desensitization. Biochemistry 2I, 3460-3467.

Noda, M., Takahashi, H., Tanabe, T., Toyosato, M., Furutani, Y., Hirose, T., Asai, M., Inayama, S., Miyata, T. \& Numa, S. (1982). Primary structure of alphasubunit precursor of Torpedo californica acetylcholine receptor deduced from cDNA sequence. Nature 299, 793-797.

Noda, M., Takahashi, H., Tanabe, T., Toyosato, M., Kikyotani, S., Hirose, T., Asai, M., Takashima, H., Inayama, S., Miyata, T. \& Numa, S. (1983a). Primary structures of beta and delta-subunit precursors of Torpedo californica acetylcholine receptor deduced from cDNA sequences. Nature 301, 25 I-255.

Noda, M., Takahashi, H., Tanabe, T., Toyosato, M., Kikyotani, S., Furutani, Y., 
Hirose, T., Takashima, H., Inayama, S., Miyata, T. \& Numa, S. (1983b). Structural homology of Torpedo californica acetylcholine receptor subunits. Nature 302, 528-532.

Numa, S. (1989). A molecular view of neurotransmitter receptors and ionic channels. Harvey Lecture, Series 83, pp. I $2 \mathrm{I}-\mathrm{I} 65$.

Oberthür, W., Muhn, P., Baumann, H., Lottspeich, F., Wittmann-Liebold, B. \& Huсно, F. (1986). The reaction site of a noncompetitive antagonist in the deltasubunit of the nicotinic acetylcholine receptor. $E M B O \mathcal{F} .5$, I 8 I $5^{-1} 8$ I 9.

Ochoa, E. L. M., Chattopadhyay, A. \& McNamee, M. G. (I989). Desensitization of the nicotinic acetylcholine receptor: molecular mechanisms and effect of modulators. Cell mol. Neurobiol. 9, I 4 I-I 78.

OchoA, E. L. M., LI, L. \& McNamee, M. G. (r992). Desensitization of central cholinergic mechanisms and neuroadaptation to nicotine. Molecular Neurobiology 4, $25 \mathrm{I}-287$.

O'Leary, M. E. \& White, M. M. (I99I). The role of aspartate-200 in ligand activation of Torpedo acetylcholine receptors. Abstract 2Ist Annual Meetings, No. 17, part I, Society for Neurociences, 14.5, p. 23.

Oswald, R. E. \& Changeux, J.-P. (1982). Crosslinking of alpha-bungarotoxin to the acetylcholine receptor from Torpedo marmorata by ultraviolet light irradiation. FEBS Lett. 139, 225-229.

Papke, R. L., Boulter, J., Patrick, J. \& Heinemann, S. (i 989). Single-channel currents of rat neuronal nicotinic acetylcholine receptors expressed in Xenopus oocytes. Nueron 3, 589-596.

Patneau, D. K. \& Mayer, M. L. (I99I). Kinetic analysis of interactions between kainate and AMPA : evidence for activation of a single receptor in mouse hippocampal neurons. Neuron 6, 785-798.

Pedersen, S. E. \& Cohen, J. B. (r $990 a$ ). d-tubocurarine binding sites are located at $\alpha-$ $\gamma$ and $\alpha-\delta$ subunit interfaces of the nicotinic acetylcholine receptor. Proc. natn. Acad. Sci. USA 87, 2785-2789.

Pedersen, S. E. \& Cohen, J. B. (I $990 b$ ). $\left[{ }^{3} \mathrm{H}\right]$ meproadifen mustard reacts with glu-262 of the nicotinic acetylcholine receptor (AChR) $\alpha$-subunit. Biophys. F. 57, 126a.

Perutz, M. F. ( 1989 ). Mechanisms of cooperativity and allosteric regulation in proteins. Quarterly Rev. Biophys. 22, I 39-236.

Popot, J. L., Sugiyama, H. \& Changeux, J. P. (1974). Démonstration de la désensibilisation pharmacologique du récepteur de l'acetylcholine in vitro avec des fragments de membrane excitable de Torpille. C. R. Acad. Sci. Paris 279, I 72 I-I 724.

Popot, J. L., Cartaud, J. \& Changeux, J. P. (i $98 \mathrm{I}$ ). Reconstitution of a functional acetylcholine receptor: incorporation into artificial lipid vesicles and pharmacology of the agonist-controlled permeability changes. Eur. F. Biochem. I I8, 203-2 I 4.

Popot, J. L. \& Changeux, J.-P. ( I 984). Nicotinic receptor of acetylcholine: structure of an oligomeric integral membrane protein. Physiol. rev. 64, I I62-I 239.

Pritchett, D. B. \& Seeburg, P. H. (I99I). $\gamma$-aminobutyric acid type A receptor point mutation increases the affinity of compounds for the benzodiazepine site. Proc. natn. Acad. Sci. USA 88, 1421-1425.

Pullman, A. (I99I). Contribution of theoretical chemistry to the study of ion transport through membranes. Chem. Rev. 9I, 793-8I2.

Radding, W., Corfield, P. W. R., Levinson, L. S., Hashim, G. A. \& Low, B. (i 988 ). $\alpha$-toxin binding to acetylcholine receptor $\alpha_{179-19 I}$ peptides: intrinsic fluorescence studies. FEBS Lett. 23I, 2 I 2-2 I 6. 
Raftery, M. A., Hukapiller, M., Strader, C. D. \& Hood, L. E. (i 980 ). Acetylcholine receptor complex of homologous subunits. Science 208, I 454-I 457.

Ralston, S., Sarin, V., Thanh, H. L., Rivier, J., Fox, J. L. \& Lindstrom, J. ( 1987 ). Synthetic peptides used to locate the $\alpha$-bungarotoxin binding site and immunogenic regions on alpha-subunits of the nicotinic acetylcholine receptor. Biochemistry $\mathbf{2 6}$, 326I-3266.

Ramoa, A. S., Alkondon, M., Aracava, Y., Irons, J., Lunt, G. G., Deshpande, S. S., Wonnacott, S., Aronstam, R. S. \& Albuquerque, E. X. (1990). The anticonvulsant MK-80 I interacts with the peripheral and central nicotinic acetylcholine receptor ion channels. F. Pharmacol. exp. Ther. 254, 7 I-82.

Rapier, C., Wonnacott, S., Lunt, G. G. \& Albuquerque, E. X. (1987). The neurotoxin histrionicotoxin interacts with the putative ion channel of the nicotinic acetylcholine receptors in the central nervous system. FEBS Lett. 212, 292-296.

Ratnam, M., Gullick, W., Spiess, J., Wan, K., Criado, M. \& Lindstrom, J. (i 986 ). Structural heterogeneity of the alpha-subunits of the nicotinic acetylcholine receptor in relation to agonist affinity alkylation and antagonist binding. Biochemistry $\mathbf{2 5}$, 4268-4275.

Revah, F., Galzi, J.-L., Giraudat, J., Haumont, P. Y., Lederer, F. \& Changeux, J.P. (I 990). The noncompetitive blocker $\left[{ }^{3} \mathrm{H}\right]$ chlorpromazine labels three amino acids of the acetylcholine receptor $\gamma$-subunit: implications for the $\alpha$ helical organization of the MII segments and the structure of the ion channel. Proc. natn. Acad. Sci. USA 87, 4675-4679.

Revah, F., Bertrand, D., Galzi, J.-L., Devillers-Thiéry, A., Mulle, C., Hussy, N., Bertrand, S., Ballivet, M. \& Changeux, J.-P. (I991). Mutations in the channel domain alter desensitization of a neuronal nicotinic receptor. Nature 353, 846-849.

Reynolds, J. A. \& Karlin, A. (1978). Molecular weight in detergent solution of acetylcholine receptor from Torpedo californica. Biochemistry $\mathbf{1 7}, 2035^{-2038}$.

Rubin, M. M. \& Changeux, J.-P. (I 966). On the nature of allosteric transitions: implications of non exclusive ligand binding. F. molec. Biol. 21, 265-274.

Safran, A., Sagi-Eisenberg, R., Neumann, D. \& Fuch, S. (1987). Phosphorylation of the acetylcholine receptor by protein kinase $\mathrm{C}$ and identification of the phosphorylation site within the receptor delta subunit. F. biol. Chem. 262, 10506-10510.

Sakmann, B., Patlak, J. \& Neher, E. (1980). Single acetylcholine activated channels show burst-kinetics in presence of desensitizing concentrations of agonist. Nature $\mathbf{2 8 6}$, $71-73$.

Sakmann, B., Methfessel, C., Mishina, M., Takahashi, T., Takai, T., Kurasaki, M., Fukuda, K. \& Numa, S. (1985). Role of acetylcholine receptor subunits in gating of the channel. Nature 318, 538-543.

Satow, Y., Cohen, G. H., Padlan, E. A. \& Davies, D. R. (i986). Phosphocholine binding immunoglobulin Fab McPC603: an X-ray diffraction study at $2.7 \AA$. $\mathrm{Mol}$. Biol. I90, 593-604.

Schneider, H. J., Güttes, D. \& Schneider, U. ( I 986). A macrobicyclic polyphenoxide as receptor analogue for choline and related ammonium compounds. Angew. Chem. Int. Ed. Engl. 25, 647-649.

Schneider, H. J., Güttes, D. \& Schneider, U. (i 988). Host-guest complexes with water-soluble macrocyclic polyphenolates including induced fit and simple elements of a proton pump. F. Am. chem. Soc. I10, 6449-6454.

Schoepfer, R., Whiting, P., Luther, M., Keyser, K., Karten, H. \& Lindstrom, J. (1989). Structure of muscle and neuronal nicotinic acetylcholine receptors. In 
Molecular Biology of Neuroreceptors and Ion Channels, vol. $\mathrm{H}_{32}$ (ed. A. Maelicke), pp. 37-53. Berlin, Heidelberg: Springer-Verlag.

Schoepfer, R., Conroy, W. G., Whiting, P., Gore, M. \& Lindstrom, J. (i 99o). Brain $\alpha$-bungarotoxin binding protein cDNAs and MAbs reveal subtypes of this branch of the ligand-gated ion channel gene family. Neuron 5, 35-48.

Sheppod, T. J., Petti, M. A. \& Dougherty, A. D. (1986). Tight, oriented binding of an aliphatic guest by a new class of water-soluble molecules with hydrophobic binding sites. F. Am. chem. Soc. 108, 6085-6087.

Sine, S. M. \& Claudio, T. (I99ז). $\gamma$ - and $\delta$-subunits regulate the affinity and the cooperativity of ligand binding to the acetylcholine receptor. 7 . biol. Chem. 266, 19369-19377.

Stroud, R. M., McCarthy, M. P. \& Shuster, M. (i990). Nicotinic acetylcholine receptor superfamily of ligand-gated ion channels. Biochemistry 29, I I0 I0-I I023.

Sussman, J., Harel, M., Frolow, F., Oefner, C., Goldman, A., Toker, L. \& Silman, I. (I99I). Atomic structure of acetylcholinesterase from Torpedo californica: a prototypic acetylcholine-binding protein. Science 253, 872-879.

Teichberg, V. I. \& Changeux, J.-P. (I976). Presence of two forms with different isoelectric points of the acetylcholine receptor in the electric organ of Electrophorus electricus and their catalytic interconversion in vitro. FEBS Lett. 67, 264-268.

Teichberg, V. I. \& Changeux, J.-P. (I 977). Evidence for protein phosphorylation and dephosphorylation in membrane fragments isolated from the electric organ of Electrophorus electricus. FEBS Lett. 74, $7 \mathrm{I}^{-}-76$.

Teichberg, V. I., Sobel, A. \& Changeux, J. P. (i977). In vitro phosphorylation of acetylcholine receptor. Nature 267, 540-542.

Tomaselli, G. F., Mclaughlin, J. T., Jurman, M., Hawrot, E. \& Yellen, G. (i 99 I). Site-directed mutagenesis alters agonist sensitivity of the nicotinic acetylcholine receptor. Biophysical $\mathcal{Y}$. 59, 33a.

Unwin, P. N. T. \& Zampighi, G. (1980). Structure of the function between communicating cells. Nature $\mathbf{2 8 3}, 545-549$.

Unwin, P. N. T., Toyoshima, C. \& Kubalek, E. (1988). Arrangement of the acetylcholine receptor subunits in the resting and desensitized states, determined by cryoelectron microscopy of crystallized Torpedo postsynaptic membranes. F. Cell Biol. I07, I I 23-1 138 .

Vandenberg, R. J., French, C. R., Barry, P. H., Shine, J. \& Schofield, P. R. (i $992 a$ ). Antagonism of ligand-gated ion channel receptors: two domains of the glycine receptor $\alpha$ subunit form the strychnine-binding site. Proc. natn. Acad. Sci. USA 89, I 765-1769.

Vandenberg, R. J., French, C. R., Barry, P. H., Shine, J. \& Schofield, P. R. ( I $992 b$ ). Three domains of the $\alpha$ subunit of the glycine receptor form the strychnine binding site. F. Cell. Biochem.: Keystone Symposia on Molecular and Cellular Biology, T2 r 3 , p. 229.

Vandlen, R. L., Wu, W. C. S., Eisenach, J. C. \& Raftery, M. A. (i 979). Studies of the composition of purified Torpedo californica acetylcholine receptor and of its subunits. Biochemistry 10, I $845^{-1} 854$.

Vernino, S., Amador, M., Luetje, C. W., Patrick, J. \& Dani, J. A. (i992). Calcium modulation and high calcium permeability of neuronal nicotinic acetylcholine receptor. Neuron 8, I 27-134.

Villar, M. J., Roa, M., Huchet, M., Hökfelt, T., Changeux, J.-P., Fahrenkrug, J., Brown, J. C., Epstein, M. \& Hersh, L. (i989). Immunoreactive calcitonin gene- 
related peptide, vaso-active intestinal polypeptide and somatostatin: distribution in developing chicken spinal cord motoneurons and role in regulation of muscle acetylcholine receptor synthesis. Eur. F. Neurosci. I, 269-287.

Villarroel, A., Herlitze, S., Koenen, M. \& Sakmann, B. (I99I). Location of a threonine residue in the $\alpha$-subunit $M_{2}$ transmembrane segment that determines the ion flow through the acetylcholine receptor channel. Proc. R. Soc. B 243, 69-74.

Wagner, K., Edson, K., Heginbotham, L., Post, M., Huganir, R. L. \& Czernik, A. J. (1991). Determination of the Tyrosine phosphorylation sites of the nicotinic acetylcholine receptor. $\mathcal{F}$. biol. Chem. 266, 23784-23789.

Waksman, G., Changeux, J.-P. \& Roques, B. (1980). Structural requirements for agonist and noncompetitive blocking action of acylcholine derivatives on Electrophorus electricus electroplaque. Mol. Pharmacol. 18, 20-27.

Walker, J. W., Takeyasu, K. \& McNamee, M. G. (I982). Activation and inactivation kinetics of Torpedo californica acetylcholine receptor in reconstituted membranes. Biochemistry 21, 5384-5389.

Watters, D. \& Maelicke, A. (I983). Organization of ligand binding sites at the acetylcholine receptor: a study with monoclonal antibodies. Biochemistry 22, I 8 II-I 8 I 9 .

Weber, M. \& Changeux, J.-P. (1974a). Binding of Naja nigricollis ${ }^{3} \mathrm{H}$-alpha-toxin to membrane fragments from Electrophorus and Torpedo electric organs. I. Binding of the tritiated alpha-neurotoxin in the absence of effector. Mol. Pharmacol. 1o, I-I 4.

Weber, M. \& Changeux, J.-P. (1974b). id. 2. Effect of the cholinergic agonists and antagonists on the binding of the tritiated $\alpha$-neurotoxin. Mol. Pharmacol. 1o, 13-34.

Weber, M. \& Changeux, J.-P. (1974c). id. 3. Effect of local anaesthetics on the binding of the tritiated $\alpha$-neurotoxin. Mol. Pharmacol. ro, 35-40.

Weiland, G., Frisman, D. \& Taylor, P. (I 979). Affinity labeling of the subunits of the membrane associated cholinergic receptor. Mol. Pharmacol. 15, 213-226.

Wess, J., Gdula, D. \& Brann, M. R. (I991). Site-directed mutagenesis of the m3 muscarinic receptor: identification of a series of threonine and tyrosine residues involved in agonist but not antagonist binding. EMBO $\mathcal{Y}$. 10, 3729-3734.

White, B. H., Howard, S., Cohen, S. G. \& Cohen, J. B. (I99I). The hydrophobic photoreagent 3 -(Trifluoromethyl)-3-m-([125 I] iodophenyl)diazirine is a novel noncompetitive antagonist of the nicotinic acetylcholine receptor. $\mathcal{F}$. biol. Chem. 266, $21595^{-2} 1607$.

White, B. H. \& Cohen, J. B. (1992). Agonist-induced changes in the structure of the acetylcholine receptor $\mathrm{M} 2$ regions revealed by photoincorporation of an uncharged nicotinic noncompetitive antagonist. $\mathcal{F}$. Biol. Chem. 267, I 5770-1 5783 .

Whiting, P., Vincent, A. \& Newsom-Davis, J. (I985). Monoclonal antibodies to Torpedo acetylcholine receptor. Characterisation of antigenic determinants within the cholinergic binding site. Eur. F. Biochem. 150, 533-539.

Wilson, P. T., Lentz, T. L. \& Hawrot, E. (i 985 ). Determination of the primary amino acid sequence specifying the $\alpha$-bungarotoxin binding site on the $\alpha$ subunit of the acetylcholine receptor from Torpedo californica. Proc. natn. Acad. Sci. USA 82, 8790-8794.

Yee, G. H. \& Huganir, R. L. (1987). Determination of the sites of cAMP-dependent phosphorylation on the nicotinic acetylcholine receptor. $\mathcal{F}$. biol. Chem. 262, I 6748-i6753. 